\title{
Breaking down the barriers: the gut microbiome, intestinal permeability and stress-related psychiatric disorders
}

\author{
John R. Kelly ${ }^{1,2}$, Paul J. Kennedy ${ }^{1}$, John F. Cryan ${ }^{1,3}$, Timothy G. Dinan ${ }^{1,2}$, \\ Gerard Clarke $^{1,2 *}$ and Niall P. Hyland ${ }^{1,4}$ \\ ${ }^{1}$ Laboratory of Neurogastroenterology, APC Microbiome Institute, University College Cork, Cork, Ireland, ${ }^{2}$ Department of \\ Psychiatry and Neurobehavioural Science, University College Cork, Cork, Ireland, ${ }^{3}$ Department of Anatomy and \\ Neuroscience, University College Cork, Cork, Ireland, ${ }^{4}$ Department of Pharmacology and Therapeutics, University College \\ Cork, Cork, Ireland
}

\section{OPEN ACCESS}

Edited by:

Brian David Gulbransen, Michigan State University, USA

Reviewed by:

Guillermo Tellez,

University of Arkansas, USA Wallace MacNaughton, University of Calgary, Canada

*Correspondence: Gerard Clarke, Department of Psychiatry and Neurobehavioural Science, 1.15 Biosciences Institute, University College Cork, Cork, Ireland g.clarke@ucc.ie

Received: 20 August 2015 Accepted: 21 September 2015 Published: 14 October 2015

Citation: Kelly JR, Kennedy PJ, Cryan JF, Dinan TG, Clarke $G$ and Hyland NP (2015) Breaking down the barriers: the gut microbiome, intestinal permeability and stress-related psychiatric

disorders.

Front. Cell. Neurosci. 9:392. doi: 10.3389/fncel.2015.00392
The emerging links between our gut microbiome and the central nervous system (CNS) are regarded as a paradigm shift in neuroscience with possible implications for not only understanding the pathophysiology of stress-related psychiatric disorders, but also their treatment. Thus the gut microbiome and its influence on host barrier function is positioned to be a critical node within the brain-gut axis. Mounting preclinical evidence broadly suggests that the gut microbiota can modulate brain development, function and behavior by immune, endocrine and neural pathways of the brain-gut-microbiota axis. Detailed mechanistic insights explaining these specific interactions are currently underdeveloped. However, the concept that a "leaky gut" may facilitate communication between the microbiota and these key signaling pathways has gained traction. Deficits in intestinal permeability may underpin the chronic low-grade inflammation observed in disorders such as depression and the gut microbiome plays a critical role in regulating intestinal permeability. In this review we will discuss the possible role played by the gut microbiota in maintaining intestinal barrier function and the CNS consequences when it becomes disrupted. We will draw on both clinical and preclinical evidence to support this concept as well as the key features of the gut microbiota which are necessary for normal intestinal barrier function.

Keywords: gut microbiota, intestinal barrier, gut-brain axis, depression, probiotics, psychobiotics

\section{The Gut Microbiome}

It is increasingly recognized that the gut microbiome might influence the core symptoms of neuropsychiatric disorders and that it might be a tractable target for novel treatment options. The mutualistic co-evolution of microbes and the human body, composed of more than $90 \%$ microbial cells and 10 million microbial genes has led to the collective being described as a "superorganism" (Nicholson et al., 2005). The most heavily colonized area of the human body is the gut, with bacterial concentrations ranging from $10^{1}-10^{3}$ cells per gram in the upper intestine to $10^{11}-10^{12}$ per gram in the colon (O'Hara and Shanahan, 2006; Derrien and van Hylckama Vlieg, 2015). Although the functional significance of the microbiome has yet to 
be fully determined (Franzosa et al., 2014), it is clear that an interlinked symbiotic relationship exists between host and microbe (Ley et al., 2008). In terms of bacterial phyla found in the gut, Firmicutes (species such as Lactobacillus, Clostridium, Enterococcus) and Bacteroidetes (species such as Bacteroides) account for the majority (Dethlefsen et al., 2007), though the other phyla such as Actinobacteria (Bifidobacteria), Proteobacteria (Escherichia coli), Fusobacteria, Verrucomicrobia, and Cyanobacteria are also present (Eckburg et al., 2005; Qin et al., 2010). Differences exist between the microbiota composition between the gut lumen and the microbiota composition which lies in close proximity to the mucus layer. For instance, gram negative Proteobacteria and Akkermansia muciniphila (Verrucomicrobia), which use mucus as a carbon and nitrogen source, adhere and reside within the mucus layer (van Passel et al., 2011). This gradient can be differentially regulated by factors such as stress (Rozee et al., 1982; Swidsinski et al., 2005; Johansson et al., 2011, 2014). A more detailed examination of the gut microbiota composition is beyond the scope of this review and the interested reader is directed to a number of excellent recent reviews on the topic (Bron et al., 2012; Jeffery et al., 2012a; Lozupone et al., 2012; O’Toole, 2012). Studies using different, but complementary, gut-microbiota directed interventions (Germ Free (GF) rodents, antibiotics, probiotics, gastrointestinal (GI) infection studies, and fecal microbiota transplantation studies) have all suggested a number of possible brain-gut signaling pathways under the influence of the gut microbiota and capable of modulating brain and behavior (Rhee et al., 2009; Grenham et al., 2011; Cryan and Dinan, 2012, 2015; Collins and Bercik, 2013; Dinan and Cryan, 2013; McVey Neufeld et al., 2013; Mayer et al., 2014a). This review will discuss the complex relationship between the gut microbiome and intestinal barrier function and examine the possible implications for stressrelated psychiatric disorders.

\section{Development, Structure, and Function of the Intestinal Epithelial Barrier}

The main function of the intestinal barrier is to regulate the absorption of nutrients, electrolytes and water from the lumen into the circulation and to prevent the entry of pathogenic microorganisms and toxic luminal substances (Farhadi et al., 2003). Furthermore, regulation of the exchange of molecules between the environment and the host through the intestinal barrier influences the equilibrium between tolerance and immunity to self and non-self-antigens (Fasano and SheaDonohue, 2005; Fasano, 2011). From a structural perspective these functions are preserved by a number of features including a mucus layer and a monolayer of epithelial cells interconnected by tight junctions (Madara, 1998). The mucus layer containing secretory immunoglobulin (Ig) A and antimicrobial peptides covers the epithelial cell lining which functions to facilitate GI transport, and as a protective layer against bacterial invasion. The colonic mucus layer is composed of two layers, an outer and inner layer composed of gel forming highly glycosylated proteins termed mucins. These are produced and maintained by goblet cells which renew the inner mucus layer approximately every hour (Johansson et al., 2011). These dynamic processes are subject to extensive and continuous interplay with the gut microbiota, disruption of which may have implications for the sustenance of key barrier functions (Yu et al., 2012; Bischoff et al., 2014).

Tight junctions on the other hand are complex protein structures that consist of transmembrane proteins such as claudin, occludin, and tricullulin (Dörfel and Huber, 2012). These transmembrane proteins connect with the opposing plasma membrane, thereby forming a mechanical link between epithelial cells and establishing a barrier to paracellular diffusion of fluid and solutes (Ivanov et al., 2010). The structure of the intestinal barrier is formed by the end of the first trimester (Montgomery et al., 1999). Epithelial cells with microvilli, goblet and enteroendocrine cells, appear by week eight of gestation and tight junctions are detected from week ten (Louis and Lin, 2009). Functional development of the intestinal barrier continues in the post natal period and is influenced by both feeding mode and diet (Cummins and Thompson, 2002; Verhasselt, 2010). Disruptions in this process, as exemplified by the underdeveloped intestinal barrier of the premature infant, can predispose to immune disorders (Groschwitz and Hogan, 2009). Indeed, there is an overlapping developmental course of the gut microbiota and intestinal barrier. The gut microbiota in the initial days of life is unstable and not particularly diverse in its make-up. By age three, however, the microbiota composition resembles that of an adult-like profile (Voreades et al., 2014). Several other factors may also influence the trajectory of microbiota development including gestational age (Barrett et al., 2013), mode of delivery (Dominguez-Bello et al., 2010), type of feeding (Penders et al., 2006), antibiotic use (Persaud et al., 2014), and exposure to family members and pets (Fujimura et al., 2010; Marques et al., 2010). The intestinal barrier acts as a shield which can be modified by the gut microbiota (Tlaskalová-Hogenova et al., 2011; Jakobsson et al., 2015) or its metabolites (Elamin et al., 2013). The mechanisms underlying the regulation of the epithelial barrier are complex. Recent evidence also suggests a novel role for noncoding RNAs, such as microRNAs, as important intermediaries in the interactions between host epithelial cells, immune cells and the gut microbiota (Cichon et al., 2014; Runtsch et al., 2014). Alterations in the gut microbiota have been associated with concomitant gut barrier dysfunction in both intestinal (Camilleri et al., 2012; Bonfrate et al., 2013; Scaldaferri et al., 2013) and extra-intestinal disorders (Vaarala et al., 2008). However, the role of the gut microbiota in disrupting the intestinal barrier in stressrelated neuropsychiatric conditions, such as depression, has not been fully investigated.

\section{Microbiome and the Blood Brain Barrier}

Structural similarities exist between the intestinal, placental and blood brain barriers (BBB; Doran et al., 2013). The $\mathrm{BBB}$ is a complex neurovascular unit (Bauer et al., 2014) consisting of central nervous system (CNS) endothelial cells which separate the lumen of blood vessels from the CNS parenchyma. Tight junctions, astrocytes and pericytes seal the capillary endothelial cells of the BBB (Daneman and Rescigno, 
2009). The tight junctions transmembrane proteins claudins, tricellulin, and occludin restrict paracellular diffusion of watersoluble substances from blood to the brain (Hawkins and Davis, 2005). Recent preclinical evidence from GF mice suggests that the microbiota can modulate the BBB. Exposure of GF adult mice to the fecal microbiota from pathogen-free donors decreased $\mathrm{BBB}$ permeability and increased the expression of tight junction proteins (Braniste et al., 2014). Moreover, monocolonization of the intestine of GF adult mice with short chain fatty acid (SCFA)producing bacterial strains normalized BBB permeability whilst sodium butyrate was associated with increased expression of occludin in the frontal cortex and hippocampus (Braniste et al., 2014). This study strengthens the hypothesis that the BBB may also be vulnerable to changes in the gut microbiota.

\section{Brain-gut-microbiota Axis}

Bidirectional signaling between the gut and the brain is regulated at neural, endocrine, and immune levels. These pathways are under the influence of the gut microbiota and together, they comprise the brain-gut-microbiota axis (Grenham et al., 2011). A cardinal function of the gut microbiota is the development and maintenance of the intestinal barrier across the lifespan (Ohland and Macnaughton, 2010; Swanson et al., 2011; Shifrin et al., 2012). It is plausible that subtle alterations in microbiota acquisition or maintenance in early life may act as a vulnerability factor, impacting on (neuro)endocrine and (neuro)immune signaling pathways of the brain-gut-microbiota axis, disruption of which may subsequently predispose to stress-related disorders in adulthood (Borre et al., 2014). Notably, animals devoid of a microbiota exhibit reduced levels of anxiety but an exaggerated neuroendocrine response to stress (Sudo et al., 2004). The most pronounced impacts of the microbiota may occur early in life during critical neurodevelopmental phases (Borre et al., 2014). It is evident that the gut microbiota is required for the normal development of the hypothalamic pituitary adrenal (HPA) axis and that there is a certain period in early life when colonization must occur to ensure normal development of this critical stress signaling pathway (Sudo et al., 2004; Moloney et al., 2014). Indeed, this concept is an extension of the hygiene hypothesis first proposed in the late 1980's (Strachan, 1989) and more recently reconceptualised as the "old friends hypothesis" (Rook et al., 2003). This proposes that encountering less microbial biodiversity may contribute to the increase in chronic inflammatory disorders including subtypes of depression (Klerman and Weissman, 1989; Weissman, 1992; Guarner et al., 2006; Rook and Lowry, 2008; Hidaka, 2012; Rook et al., 2013, 2014; Williamson et al., 2015).

The interaction between the immune system, the gut microbiota and the intestinal barrier may be of particular importance to health at the other extreme of life, aging. Aging is characterized by chronic low-grade inflammation (termed "inflammaging") as evidenced by increased circulating levels of Tumor necrosis factor-alpha (TNF- $\alpha$ ), interleukin (IL)-6 and Creactive protein (CRP); inflammatory molecules known to affect mood and cognition (Frasca and Blomberg, 2015). The fact that the gut microbiota are key regulators of immune function and inflammatory responses, it is likely that a change in the composition of the gut microbiota during aging plays a role in the gradual activation of the immune system and consequently inflammaging (Prenderville et al., 2015), possibly via an impact on intestinal permeability. Indeed, the ELDERMET consortium demonstrated that the elderly have a distinct microbiota profile, characterized by greater inter-individual variation compared to younger adults (Claesson et al., 2011). Of note, differences in microbiota composition were more pronounced between frail elderly subjects and healthy elderly subjects. Moreover, certain gut microbiota signatures were linked to measures of frailty, co-morbidity, nutritional status, and markers of inflammation (Claesson et al., 2012).

\section{Stress, the Gut Microbiota and Barrier Function}

Stress can impact on the developmental trajectory of the intestinal barrier (Smith et al., 2010; Lennon et al., 2013) and has been associated with an increase in gut permeability (Söderholm et al., 2002). Indeed, the effects of stress on intestinal permeability are complex and likely involve both the gut and the brain. Corticotrophin releasing factor (CRF) and its receptors (CRFR1 and CRFR2), play a key role in stress-induced gut permeability dysfunction (Overman et al., 2012; RodiñoJaneiro et al., 2015; Taché and Million, 2015). In response to an acute stressor, colonic paracellular permeability increases and has been associated with the development of visceral hypersensitivity (Ait-Belgnaoui et al., 2005). In a mouse model of chronic depression, elevated central CRH expression occurred concomitantly with changes in the gut microbiota (Park et al., 2013). Early life stress has also been demonstrated to enhance plasma corticosterone in rat pups and is associated with an increase in intestinal permeability and bacterial translocation to the liver and spleen. This effect appeared to predominate in the colon (Moussaoui et al., 2014). Of note, stress-induced changes in the HPA axis and autonomic nervous system display sensitivity to probiotic intervention (Lactobacillus helveticus R0052 and Bifidobacterium longum R0175); (Ait-Belgnaoui et al., 2014). Moreover, these probiotics also restored colonic tight junction integrity in stressed mice (Ait-Belgnaoui et al., 2014). Probiotics have also been demonstrated to influence bacterial adhesion and translocation to mesenteric lymph nodes in response to stress (Zareie et al., 2006). Lactobacillus farciminis in particular not only suppresses stress-induced changes in permeability, HPA axis activity, endotoxaemia, and neuroinflammation (AitBelgnaoui et al., 2012), but also beneficially influences the mucus barrier (Da Silva et al., 2014). Human studies further confirm that acute-stress paradigms can affect intestinal permeability. In a public speaking based stressor, small intestinal permeability was significantly increased, however, this was only observed in those subjects who also responded with a significant elevation of cortisol (Vanuytsel et al., 2014). In a different acute stress model using a cold pain stressor, albumin permeability increased, though in females only (Alonso et al., 2012).

Stressful early-life events are strongly associated with the development of depression later in life (Heim et al., 2000). 
The interaction between stress, the HPA axis and the immune system is well established (Baes et al., 2014; Hueston and Deak, 2014). In recent years it has emerged that the gut microbiota mediates this interaction (De Palma et al., 2014b). Early-life maternal separation, for example, results in a significant decrease in fecal Lactobacillus numbers three days post-separation and this correlated with stress-related behaviors (Bailey and Coe, 1999). In a mouse model of social disruption, stress-induced alterations in the microbiota were accompanied by changes in cytokine and chemokine levels (Bailey et al., 2011). Several other studies have verified that stress can remodel the gut microbiota composition (Wang and Wu, 2005; O'Mahony et al., 2009; Galley et al., 2014a,b; De Palma et al., 2015). This is also relevant prenatally, as infants of mothers with high selfreported stress and high salivary cortisol concentrations during pregnancy had a significantly higher relative abundance of Proteobacteria and lower relative abundances of lactic acid bacteria (Lactobacillus, Lactoccus, Aerococcus) and Bifidobacteria. However, it is currently unclear whether this effect was mediated via maternal microbial transmission or through microbiotaindependent events. Nonetheless, those infants with altered microbiota composition exhibited a higher level of infant GI symptoms and allergic reactions, highlighting the functional consequences of aberrant colonization patterns in early life (Zijlmans et al., 2015). Recent preclinical evidence showed that maternal stress altered the vaginal microbiota, decreasing Lactobacillus, with implications for the metabolic profile and neurodevelopment in the offspring (Jašarevic et al., 2015a,b).

A dysfunctional intestinal barrier could permit a microbiota driven proinflammatory state with implications for the brain (see Figure 1). The sequence of this process is not yet clear. An increase in gut permeability could precede mucosal inflammation to induce the inflammatory response and thus culminate in a feed-forward cycle between inflammatory responses and barrier dysfunction. This could subsequently maintain and exacerbate the low grade inflammatory response. Alternatively, systemic inflammation could increase intestinal barrier permeability and thus allow translocation of commensal bacteria with further implications for systemic inflammation. Indeed, the source of the low grade inflammation which has been reported in depression has not been isolated to a particular source. Irrespective of the sequence, both processes could engage the gut microbiota. Higher IgA- and IgM-mediated immune responses directed against lipopolysaccharides (LPS) of certain commensal gram negative gut bacteria have been shown in depressed patients (Maes et al., 2008, 2012). The implication being that the presence of such responses may have occurred subsequent to disruption of the intestinal barrier. Moreover, bacterial DNA has been detected in whole serum from depressed patients who also displayed increased Toll-like receptor (TLR)-4 expression on peripheral mononuclear blood cells compared to healthy controls (Kéri et al., 2014). To date, two published cross sectional studies have investigated the gut microbiota composition in depression. The first found an increase in Bacteroidales and a decrease in Lachnospiraceae compared to controls. However, there were no significant differences in species richness, $\alpha$-diversity, or operational taxonomic units (Naseribafrouei et al., 2014). In the second study increased levels of Enterobacteriaceae and Alistipes were observed. Moreover, Fecalibacterium levels were reduced in the depressed group and negatively correlated with severity of depressive symptoms (Jiang et al., 2015). In the context of alcohol abuse, a relationship between the microbiota, barrier function and comorbid depression has recently been reported (Leclercq et al., 2014a). Microbiota-derived LPS and peptidoglycans (PGN) were demonstrated to cross the gut barrier and activate their respective receptors, TLR4 and TLR2 in peripheral blood mononuclear cells. Although chronic alcohol consumption inhibited the NF-кB pathway, it activated protein kinase/activator protein 1 pathway and IL-8 and IL-1B. In contrast, short term alcohol withdrawal was associated with the recovery of TLR 4 receptors. The same group also demonstrated that increased intestinal permeability occurred in a sub group of alcohol-dependent subjects which were associated with higher depression and anxiety scores as well as an altered gut microbiota profile (Leclercq et al., 2014b).

\section{Irritable Bowel Syndrome}

Irritable bowel syndrome (IBS) is a stress-related functional brain-gut-microbiota axis disorder associated with an altered gut microbiota profile (Carroll et al., 2011; Jeffery et al., 2012c; Collins, 2014; De Palma et al., 2014a; Simrén, 2014; Soares, 2014; Rajilic-Stojanovic et al., 2015) and increased intestinal permeability (Dunlop et al., 2006; Rao et al., 2011; Camilleri et al., 2012). Moreover, a significant proportion of IBS patients also suffer from depressive and anxiety symptoms (Singh et al., 2012; Lucas et al., 2014); furthermore, these psychiatric symptoms increase with the greater frequency and severity of GI symptoms (Pinto-Sanchez et al., 2015). In addition, alterations in brain circuits involved in attention, emotion, pain (Labus et al., 2009; Blankstein et al., 2010; Tillisch et al., 2013) together with deficits in hippocampal-mediated visuospatial memory (Kennedy et al., 2012, 2014) have been noted in the disorder. In particular, an altered Firmicutes: Bacteroidetes ratio has been linked to IBS and an association between Firmicutes, Proteobacteria and IBS symptom scores has been demonstrated (Rajilic-Stojanovic et al., 2011). A recent meta-analysis of clinical studies to identify and assess the various diagnostic tests indicated that a combination of intestinal permeability, Rome I criteria and fecal calprotectin (see Table 1) provided the highest positive likelihood ratio for predicting IBS (Sood et al., 2015). Although not captured in this meta-analysis, and not part of routine clinical practice, the addition of gut microbiota profiling may deliver further diagnostic accuracy (Casen et al., 2015). For example, IBS subtypes have been stratified according to their microbiota profiles, specifically those with an increased Firmicutes: Bacteroidetes ratio (Jeffery et al., 2012b). Furthermore, depression was the most robust clinical discriminator between a high Firmicutes: Bacteroidetes ratio in IBS patients relative to IBS patients with a healthy-like microbiota signature (Jeffery et al., 2012b). In addition, the order Actinomycetales and the family Actinomycetaceae were inversely associated with clinically significant depression (Jeffery et al., 2012b). 


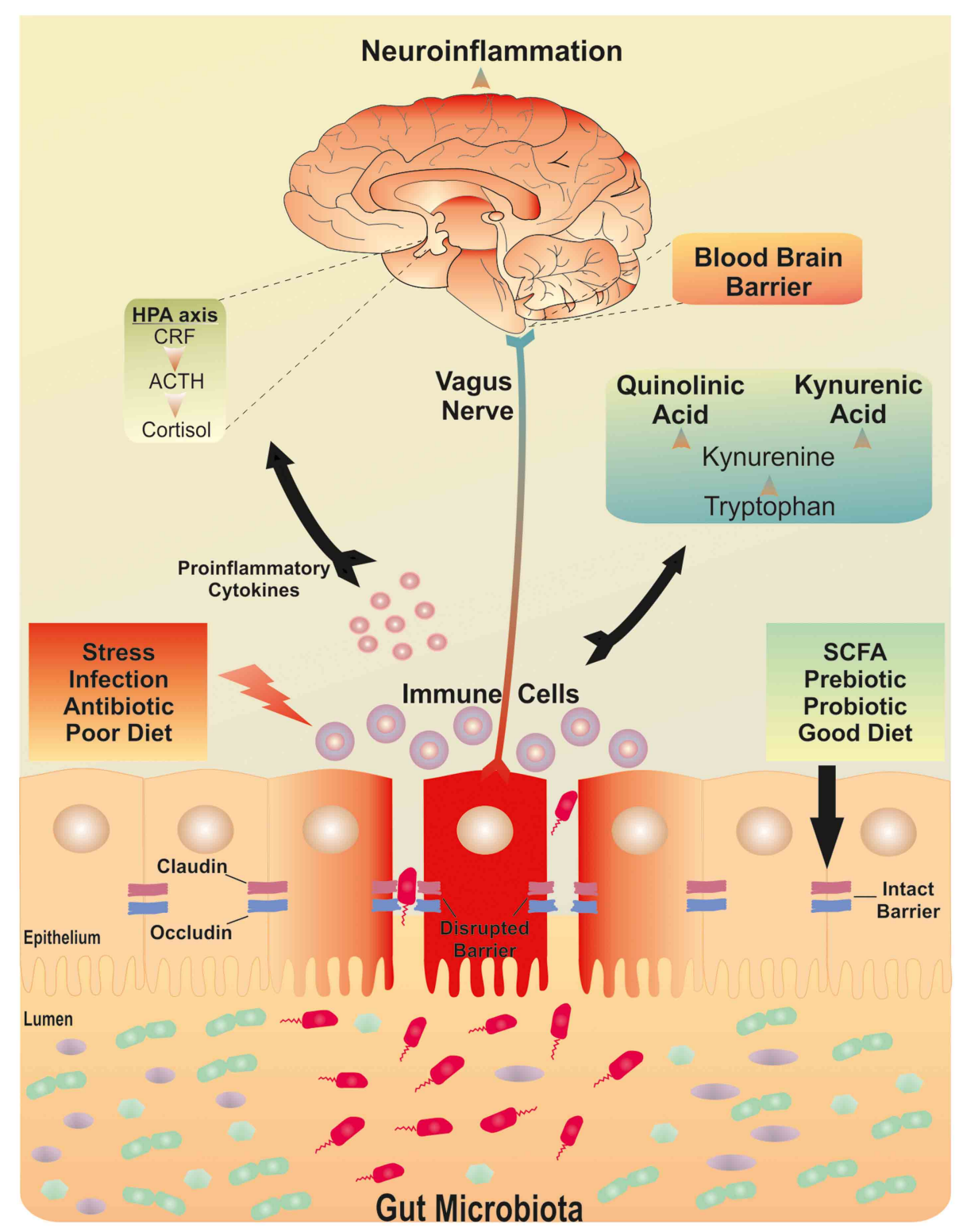

FIGURE 1 | The brain-gut-microbiota axis. Postulated signaling pathways between the gut microbiota, the intestinal barrier and the brain. A dysfunctional intestinal barrier or "leaky gut" could permit a microbiota-driven proinflammatory state with implications for neuroinflammation.

Although the microbiota varies along the length of the gastrointestinal tract, the majority of studies use fecal microbiota sampling as a representative of global changes, however site specific changes may influence the ensuing immune consequences. For example mucosal jejunal tissue from diarrheapredominant IBS patients is also associated with increased activation of mucosal B lymphocytes, plasma cells and mucosal IgG production (Vicario et al., 2015). Of note in this study, humoral activity markers positively correlated with depressive symptoms (Vicario et al., 2015). Further studies need to be conducted to disentangle the contributing role of an exaggerated or aberrant immune response, changes in intestinal permeability and psychiatric co-morbidities in IBS. However, individuals with pre-existing psychological disorders are known to be at an increased risk of developing post-infectious IBS (PIIBS) in particular (Thabane and Marshall, 2009). Variations in several genes associated with bacterial recognition, the inflammatory response and epithelial integrity including TLR9, IL-6 and cadherin 1 genes have been identified as risk factors for the development of PI-IBS (Craig and Quigley, 2010; Villani et al., 2010). A longitudinal study which examined the rate of IBS development following an accidental outbreak of E. coli 0157:H7 into a town's (Walkerton) water supply identified an increased rate of IBS two years after the outbreak (Marshall, 2009). A subsequent study further identified a modest increase in intestinal permeability amongst this IBS cohort 
TABLE 1 | Markers of intestinal permeability.

\begin{tabular}{|c|c|c|c|c|}
\hline Permeability test & Sample & Measures & Clinical/Preclinical & Representative citation \\
\hline \multicolumn{5}{|l|}{ CHALLENGE TESTS } \\
\hline Lactulose/Mannitol & Urine & Small intestine permeability & Clinical and preclinical & Vanuytsel et al., 2014 \\
\hline Lactulose/L-rhamnose & Urine & Small intestine permeability & Clinical and preclinical & Keszthelyi et al., 2014 \\
\hline Sucrose & Urine & Gastric permeability & Clinical and preclinical & Mujagic et al., 2014 \\
\hline Sucralose & Urine & Colonic permeability & Clinical and preclinical & Anderson et al., 2004 \\
\hline Polyethylene glycols & Urine & Entire intestine permeability & Clinical and preclinical & Rao et al., 2011 \\
\hline${ }^{51} \mathrm{Cr}-\mathrm{EDTA}$ & Urine & Entire intestine permeability & Clinical and preclinical & Grootjans et al., 2010 \\
\hline \multicolumn{5}{|l|}{ CIRCULATING MARKERS } \\
\hline Zonulin & Plasma & Small intestine epithelial cell damage & Clinical and preclinical & Fasano, 2011 \\
\hline Intestinal fatty acid binding protein (I-FABP) & Plasma & Small intestine permeability & Clinical and preclinical & Derikx et al., 2009 \\
\hline Citrulline & Plasma & Small intestine epithelial cell damage & Clinical and preclinical & Crenn et al., 2000 \\
\hline$\alpha$ Glutathione S-transferase ( $\alpha$ GST) & Plasma & Epithelial cell damage & Clinical and preclinical & McMonagle et al., 2006 \\
\hline Claudin-3 & Urine & Epithelial cell damage & Clinical and preclinical & Patel et al., 2012 \\
\hline Lipopolysacharide Binding protein (LBP) & Plasma & Indirect evidence of permeability deficit & Clinical and preclinical & Pasternak et al., 2010 \\
\hline Endotoxin core antibodies (EndoCAb) & Plasma & Entire intestine permeability & Clinical and preclinical & Ammori et al., 2003 \\
\hline D-Lactate & Plasma & Entire intestine permeability & Clinical and preclinical & Poeze et al., 1998 \\
\hline $\begin{array}{l}\text { Fluorescein isothiocyanate-dextran } \\
\text { (FITC-Dextran 4) }\end{array}$ & Plasma & Entire intestine permeability & Preclinical & Moussaoui et al., 2014 \\
\hline \multicolumn{5}{|l|}{ FECAL MARKERS } \\
\hline Calprotectin & Feces & Nonspecific marker of gut inflammation & Clinical and preclinical & de Magistris et al., 2010 \\
\hline Zonulin & Feces & Marker of intestinal permeability & Clinical & Lamprecht et al., 2012 \\
\hline \multicolumn{5}{|l|}{ EX VIVO } \\
\hline Ussing chamber & Ex vivo biopsies & $\begin{array}{l}\text { Tranepithelial electrical resistance and } \\
\text { macromolecule flux }\end{array}$ & Clinical and preclinical & Piche et al., 2009 \\
\hline
\end{tabular}

(Marshall et al., 2004); an association between this outbreak and depression was also identified (Garg et al., 2006). However, whether there is an association between a deficient barrier and the onset of depressive-like symptoms amongst this cohort has yet to be determined. Similarly, an outbreak of Shiga toxin-producing E. coli $\mathrm{O} 104$ in Germany increased self-reported depressive and anxiety symptoms measured six months after the infection (Löwe et al., 2014). However, intestinal permeability was not measured in this study.

Independent of the emergence of IBS following a GI infection, sickness behaviors and depressive like behaviors are notable consequences of peripheral infections (Dantzer et al., 2008). Several enteric pathogens have been shown to have a detrimental effect on the intestinal barrier (Paesold et al., 2002; Berkes et al., 2003; Flynn and Buret, 2008) which can occur via paracellular (Ferrier et al., 2003; Wu et al., 2011) or transcellular routes (Kalischuk et al., 2009). It is well established that GI infection produces elevated anxiety-like behavior in mice (Lyte et al., 2006). Antibiotics can also alter the diversity of the composition of the gut microbiota (Dethlefsen and Relman, 2011; Willing et al., 2011) with potential implications for neurochemistry and behavior (Bercik and Collins, 2014). In addition, certain antibiotics may have an adverse effect on the intestinal barrier. For example, rats administered oral clindamycin for four days, followed by oral infection with Salmonella enteritidis showed increased intestinal permeability as measured by $24 \mathrm{~h}$ urinary CrEDTA compared to the uninfected control group (van Ampting et al., 2010). Similarly, inflammatory bowel disease (IBD), a GI disease characterized by overt inflammation, is also associated with intestinal barrier dysfunction (Laukoetter et al., 2008; Marchiando et al., 2010; Antoni et al., 2014) increased intestinal permeability (Gerova et al., 2011) immune dysregulation and an altered gut microbiota (Sartor and Mazmanian, 2012). IBD is also associated with a higher prevalence of anxiety and depressive disorders (Walker et al., 2008). Moreover, stress can adversely affect the course of IBD (Mittermaier et al., 2004; Mawdsley and Rampton, 2005). Both Crohn's disease and ulcerative colitis exhibit alterations in the expression of the tight junction proteins, claudin and occludin (Heller et al., 2005; Zeissig et al., 2007). Interestingly, recent preclinical evidence suggests that chronic intestinal inflammation alters hippocampal neurogenesis (Zonis et al., 2015) which itself in influenced by the gut microbiota (Ogbonnaya et al., 2015).

\section{Candidate Pathways to Barrier Dysfunction}

\section{Serotonin}

Serotonin is a critical signaling molecule in the brain-gutmicrobiota axis (O'Mahony et al., 2015) and is involved in a wide range of physiological functions. In the GI tract it plays an important role in secretion, sensing and signaling (Mawe and Hoffman, 2013). The largest reserve of 5-HT is located in enterochromaffin cells (Berger et al., 2009). Emerging evidence 
also suggests that the serotonergic system may be under the influence of gut microbiota, especially, but not limited to, periods prior to the emergence of a stable adult-like gut microbiota (Desbonnet et al., 2008; El Aidy et al., 2012; Clarke et al., 2013). Mucosal 5-HT has been demonstrated to play a direct role in the regulation of intestinal permeability. 5-hydroxytryptophan (5-HTP), a precursor of 5HT, significantly decreased intestinal permeability in healthy control subjects and this was associated with a redistribution of ZO-1. Whilst in IBS patients 5-HTP resulted in a further decrease in occludin expression (Keszthelyi et al., 2014). The gut microbiota itself is also an important, but frequently overlooked, regulator of 5-HT synthesis and secretion. For example, colonic tryptophan hydroxylase 1 (Tph1) mRNA and protein were increased in humanized GF and conventionally raised mice. Bacterial metabolites have also been demonstrated to influence Tph1 transcription in a human enterochromaffin cell model (Reigstad et al., 2015). Others have demonstrated that distinct microbial metabolites produced by spore forming bacteria increase colonic and blood 5-HT in chromaffin cell cultures (Yano et al., 2015).

\section{Toll-like Receptors}

Toll-like receptors (TLRs) are evolutionarily conserved type I transmembrane proteins that function as pattern recognition receptors (PRRs) and recognize microbial components (PålssonMcDermott and O'Neill, 2007; Mogensen, 2009; McCusker and Kelley, 2013). TLRs recognize microbe-associated molecular patterns (MAMPs) which are shared by many microorganisms. TLRs are expressed by a number of immune cells, including dendritic cells (DCs), macrophages, neutrophils, T cells, and $B$ cells but are also found on non-immune cells, such as epithelial and endothelial cells (Hopkins and Sriskandan, 2005). Activation of TLRs initiates signal transduction pathways and triggers the expression of genes that control innate immune responses and further guide development of antigen-specific acquired immunity (Akira and Takeda, 2004). Thus, TLRs might serve as a molecular channel between microbiota alterations and immune homeostasis (Rogier et al., 2015). As well as playing a role in maintaining intestinal barrier function (Cario et al., 2004; Rakoff-Nahoum et al., 2004), TLRs also promote epithelial cell proliferation, secretion of IgA into the gut lumen and expression of antimicrobial peptides (Abreu, 2010). Dysregulation of these processes, or excessive TLR activation, can result in chronic inflammatory and over-exuberant repair responses. Recent evidence suggests that the TLR3 synthetic agonist, Poly(I:C) not only decreases epithelial resistance in the small intestine but also promoted thinning of the mucosal layer (Moyano-Porcile et al., 2015).

\section{Short Chain Fatty Acids}

The microbiota produces several bioactive metabolic products, including polysaccharides, lycosylceramides, nucleic acids, structural proteins, and SCFAs (Olle, 2013; Russell et al., 2013). SCFAs (butyrate, acetate, and propionate) are neurohormonal signaling molecules produced by certain classes of bacteria such as Bacteroides, Bifidobacterium, Propionibacterium, Eubacterium, Lactobacillus, Clostridium, Roseburia, and
Prevotella (Macfarlane and Macfarlane, 2012). SCFAs are transported by monocarboxylate transporters, which notably are expressed at the BBB (Steele, 1986; Vijay and Morris, 2014). Indeed a recent preclinical imaging study demonstrated that microbiota-derived acetate can cross the BBB where it can subsequently alter hypothalamic gene expression (Frost et al., 2014). SCFAs are also pivotal in the maintenance of the intestinal barrier (Peng et al., 2007), with physiological concentrations having demonstrable effects on intestinal barrier function (Suzuki et al., 2008). Butyrate has been demonstrated to influence expression of tight junction proteins including claudin-2, occludin, cingulin, and zonula occludens proteins (ZO-1, ZO-2; Plöger et al., 2012). Butyrate has also been shown to facilitate the association between transcription factors and the claudin-1 promoter (Wang et al., 2012a), increase AMP-activated protein kinase (AMPK) activity (Peng et al., 2009) and to reduce bacterial translocation (Lewis et al., 2010). Interestingly, given the importance of butyrate in the maintenance of the intestinal barrier, IBS has been associated with a reduction in butyrate producing gut micro-organisms (Pozuelo et al., 2015). It has, however, proven difficult thus far to demarcate the CNS consequences of SCFA-mediated effects on intestinal barrier function from a direct action in the brain. It is also notable that there is still considerable debate surrounding the ability of physiological levels of SCFAs to impact substantially on relevant behaviors via central mechanisms, albeit that higher doses do have clear behavioral consequences (MacFabe et al., 2007; Macfabe, 2012).

Other mechanisms by which the microbiota may signal to the underlying mucosa, or mucosal immune system, include delivery to an underlying subset of dendritic cells via small intestine goblet cells (Artis, 2008; McDole et al., 2012). It has also been postulated that bacterial components can cross the intestinal barrier in small lipoprotein vesicles called exosomes which contain protein, nucleic acids, sugars and lipids. These exosomes can then transfer from dendritic cells to T cells in the draining lymph nodes and enter the circulation (Smythies and Smythies, 2014b). Consequently, $\mathrm{T}$ cells may receive epigenetic material from gut bacteria, either by direct endocytosis, or via afferent exosomes (Smythies and Smythies, 2014a). More recently, identification of "neuropods" as a pathway by which bacteria can communicate via intestinal enterochromaffin cells to the nervous system provides further insight into pathways responsible for gut to brain communication (Bohórquez et al., 2015).

\section{Restoration and Maintenance of a Healthy Intestinal Barrier}

Diet, composition of the gut microbiota and health are intrinsically linked (Daniel et al., 2014; David et al., 2014). Diets consisting of fast food and processed food have been associated with increased intestinal permeability and depressive symptoms (Sánchez-Villegas et al., 2012). Conversely, diets rich in vegetables, fruit and fish are associated with lower depressive symptoms (Akbaraly et al., 2009; Jacka et al., 2010, 2011, 2014; Ruusunen et al., 2014). Both preclinical and clinical studies show that dietary components can alter 
intestinal permeability (Cani et al., 2008; Ulluwishewa et al., 2011; Stenman et al., 2012; Teixeira et al., 2012; Hamilton et al., 2015). In particular, high fat diets are associated with a greater translocation of LPS across the gut wall (Moreira et al., 2012). Moreover, meals rich in fiber and fruit have been demonstrated to reduce high fat/high carbohydrate meal-induced increases in plasma LPS levels, the inflammatory response and the expression of TLR2 and TLR4 (Ghanim et al., 2009). High fat diets can also influence the gut microbiota and have been demonstrated to increase the Firmicutes: Bacteriodetes ratio and induce the growth of Enterobacteriaceae (Kim et al., 2012). This effect was accompanied by increased plasma and fecal endotoxin levels and reduced expression of the tight junction proteins claudin-1 and occludin in the colon (Kim et al., 2012). High fat diet-induced increases in LPS translocation and barrier function are also sensitive to restoration by organisms such as Akkermansia muciniphila (Everard et al., 2013).

\section{Pre- and Pro-biotics}

A probiotic is defined as a live bacteria which when administered in adequate amounts confers a health benefit on the host (WHO, 2001; Petschow et al., 2013). Although, previous probiotic health claims have been exaggerated (Shanahan, 2002; Sanders, 2003; Hoffmann et al., 2013) it is clear that certain strains demonstrate beneficial effects on the intestinal barrier across the lifespan via a number of mechanisms and mediators (Eutamene and Bueno, 2007; Mennigen and Bruewer, 2009). The term "psychobiotics" has been recently conceived to encompass the sub-types of probiotics that may be capable of modulating the brain-gut-microbiota axis to have a beneficial effect on mood, anxiety and cognition (Dinan et al., 2013). However, despite Logan and Katzman's initial proposal of an augmenting role of probiotics in depression (Logan and Katzman, 2005), there are currently no published studies of the clinical use of probiotics in depressed patients. One double-blind, placebo-controlled trial of probiotic supplementation conducted in patients diagnosed with schizophrenia, failed to show superiority over placebo supplementation (Dickerson et al., 2014). Several studies have been conducted in the healthy population (see Table 3 ). In the context of primarily non-psychiatric disorders (see also Table 3), B. lactis augmented formula, fed to preterm infants, resulted in decreased intestinal permeability as measured by the lactulose/mannitol ratio at two, seven and 30 days post birth (Stratiki et al., 2007). In a double-blinded, placebocontrolled, cross-over study L. rhamnosus $19070-2$ and $L$. reuteri DSM 12246 were administered for six weeks to 41 children with moderate and severe atopic dermatitis. This probiotic combination decreased associated GI symptoms and influenced small intestinal permeability as measured by the lactulose-mannitol test (Rosenfeldt et al., 2004). In healthy adults $L$. plantarum WCFS1 administered to the duodenum via feeding catheter, increased $\mathrm{ZO}-1$ and occludin compared to placebo. In the in vitro arm of the same study L. plantarum induced translocation of $\mathrm{ZO}-1$ to the tight junction region in human epithelium, though the authors point out that the effects on occludin were minor compared with those seen in vivo. Furthermore, L. plantarum was shown to activate TLR2 signaling (Karczewski et al., 2010). In a randomized, doubleblinded, placebo controlled trial, a 14 week course of probiotic supplementation in athletes resulted in a decrease in fecal zonulin (see Table 1) in the probiotic group compared to the control group after a period of intense exercise measured at baseline and at 14 weeks (Lamprecht et al., 2012).

Some of the strongest evidence for the clinical role of probiotics comes from studies in patients with the brain-gutaxis disorder, IBS (Whelan and Quigley, 2013; Orel and Kamhi Trop, 2014). A number of probiotics and commensal organisms, primarily lactic acid bacteria, have been shown to ameliorate certain IBS symptoms (Hoveyda et al., 2009; Clarke et al., 2012; Ortiz-Lucas et al., 2013; Yoon et al., 2014; Didari et al., 2015). Some of these beneficial effects may, at least, relate to the anti-inflammatory effects of particular organisms (O'Mahony et al., 2005). Moreover, probiotics in accordance with preclinical evidence (see Table 2) can improve intestinal barrier function under pathological conditions in human populations. In a randomized single blind placebo controlled study a fermented milk drink containing Streptococcus thermophilus, L. bulgaricus, L. acidophilus, and B. longum decreased small intestinal permeability, though colonic permeability was unaltered (Zeng et al., 2008).

A prebiotic effect is defined as the selective stimulation of growth and/or activity(ies) of one or a limited number of microbial genus(era)/species in the gut microbiota that confer(s) health benefits to the host (Gibson, 2004; Roberfroid et al., 2010). Preclinical and clinical studies demonstrate that certain prebiotics alter the gut microbiota, can reduce low grade inflammation and improve metabolic function (Everard et al., 2011; Greiner and Bäckhed, 2011; da Silva et al., 2013; Dewulf et al., 2013; Bindels et al., 2015). Evidence also suggests that prebiotic galacto-oligosaccharides (GOS) can improve intestinal barrier function in rats (Zhong et al., 2009). Moreover, mice treated with prebiotics exhibit improvements in intestinal permeability, tight junction integrity, decreased plasma LPS and cytokine levels in addition to decreased hepatic expression of inflammatory and oxidative stress markers (Cani et al., 2009). Prebiotics have also been shown to influence brain neurochemistry and behavior. GOS, for example, increased hippocampal neurotrophin levels and the expression $\mathrm{N}$-methyl-d-aspartate receptor subunits in the rat frontal cortex (Savignac et al., 2013). Behaviorally, a combination of GOS and polydextrose attenuated anxiety-like behavior in rats and induced alterations in the gut microbiota composition (Mika et al., 2014). In the context of IBS, GOS also appeared to influence the gut microbiota and improved anxiety scores (Silk et al., 2009). Furthermore, in healthy adults, administration of GOS significantly decreased the cortisol awakening response and decreased attentional vigilance to negative vs. positive information in a dot-probe task compared to placebo (Schmidt et al., 2015).

\section{Conclusion and Future Perspectives}

The area of microbiome research needs to move beyond purely compositional assessments to understanding the 
TABLE 2 | Preclinical studies of probiotics and intestinal barrier.

\begin{tabular}{|c|c|c|}
\hline Probiotic & Effects & References \\
\hline \multirow[t]{2}{*}{ VSL\#3 } & $\begin{array}{l}\text { Normalization of colonic physiologic function and barrier integrity; reduction in } \\
\text { mucosal secretion of TNF } \alpha \text { and IFN } \gamma \text { and an improvement in histologic disease }\end{array}$ & Corridoni et al., 2012 \\
\hline & $\begin{array}{l}\text { Decreased ileal paracellular permeability, decrease claudin-2 and increase occludin in } \\
\text { a mouse model of ileitis }\end{array}$ & \\
\hline VSL\#3 (protein soluble factor) & Enhanced barrier function and resistance to Salmonella invasion & Madsen et al., 2001 \\
\hline VSL\#3 & $\begin{array}{l}\text { Prevented the increase in epithelial permeability in DSS-induced acute colitis and } \\
\text { prevented the decrease in expression and redistribution of occludin, zonula } \\
\text { occludens-1, and claudin-1, }-3,-4 \text {, and }-5\end{array}$ & Mennigen et al., 2009 \\
\hline VSL\#3 & $\begin{array}{l}\text { VSL\#3 attenuated intestinal barrier damage and reduced bacterial translocation in an } \\
\text { LPS induced mouse model of sepsis }\end{array}$ & Ewaschuk et al., 2007 \\
\hline Lactobacillus rhamnosus and L. acidophilus & Attenuated the damage caused by Shigella dysenteriae & Moorthy et al., 2009 \\
\hline Lactobacillus plantarum & $\begin{array}{l}\text { Prevented the rearrangement of claudin-1, occludin, JAM-1 and ZO-1 proteins } \\
\text { induced by Escherichia coli }\end{array}$ & Qin et al., 2009 \\
\hline Lactobacillus reuteri & $\begin{array}{l}\text { Reduced levels of colonic mucosal adherent and translocated bacteria and } \\
\text { attenuated the development of the colitis in interleukin IL-10 gene deficient mice }\end{array}$ & Madsen et al., 1999 \\
\hline $\begin{array}{l}\text { Lactobacillus rhamnosus GG culture supernatant } \\
\text { (LGG-s) }\end{array}$ & $\begin{array}{l}\text { Pretreatment significantly inhibited alcohol-induced intestinal permeability defects, } \\
\text { endotoxemia and subsequent liver injury }\end{array}$ & Wang et al., 2012b \\
\hline \multirow[t]{2}{*}{$\begin{array}{l}\text { Lactobacillus rhamnosus OLL2838 (live and } \\
\text { heat-killed) }\end{array}$} & $\begin{array}{l}\text { Protected against the increase in mucosal permeability associated with DSS-induced } \\
\text { colitis }\end{array}$ & Miyauchi et al., 2009 \\
\hline & $\begin{array}{l}\text { Increased expression of ZO-1 and myosin light-chain kinase in intestinal epithelial } \\
\text { cells isolated from mice of the heat-killed OLL2838 group }\end{array}$ & \\
\hline \multirow[t]{3}{*}{ Lactobacillus casei DN-114 001 (lysate-Lc) } & $\begin{array}{l}\text { Increased the numbers of CD4(+)FoxP3(+) Tregs in mesenteric lymph nodes, } \\
\text { decreased the production of TNF } \alpha \text { and IFN } \gamma \text {, and anti-inflammatory IL-10 in Peyer's } \\
\text { patches and the large intestine; changed the gut microbiota composition in DSS } \\
\text { colitis }\end{array}$ & Zakostelska et al., 2011 \\
\hline & $\begin{array}{l}\text { Lc also resulted in a significant protection against increased intestinal permeability } \\
\text { and barrier dysfunction }\end{array}$ & \\
\hline & $\begin{array}{l}\text { Lc treatment prevented LPS-induced TNF } \alpha \text { expression in RAW } 264.7 \text { cell line by } \\
\text { down-regulating the NF-kB signaling pathway }\end{array}$ & \\
\hline
\end{tabular}

Lactobacillus brevis SBC8803 polyphosphate (poly P)
Suppressed the oxidant-induced increase in intestinal permeability in the mouse small intestine

Daily intrarectal administration of poly P improved the inflammatory profile and survival rate when administered to DSS mice
Segawa et al., 2011

\section{(1)

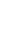




\section{TABLE 2 | Continued}

\begin{tabular}{|c|c|c|}
\hline Probiotic & Effects & References \\
\hline Lactobacillus plantarum 299v & Administration for one week abolished E. coli-induced increase in permeability & Mangell et al., 2002 \\
\hline $\begin{array}{l}\text { Lactobacillus helveticus and Lactobacillus } \\
\text { rhamnosus }\end{array}$ & $\begin{array}{l}\text { Administration one week prior to, and concurrently with, Citrobacter rodentium } \\
\text { attenuated } C \text {. rodentium-induced barrier dysfunction, epithelial hyperplasia, and } \\
\text { binding of the pathogen to host colonocytes }\end{array}$ & Rodrigues et al., 2012 \\
\hline $\begin{array}{l}\text { Lactobacillus rhamnosus LOCK0900, L. } \\
\text { rhamnosus LOCK0908 and L. casei LOCK0919 }\end{array}$ & $\begin{array}{l}\text { Colonization of GF mice enhanced the integrity of gut mucosa and ameliorated } \\
\text { allergic sensitization }\end{array}$ & Kozakova et al., 2015 \\
\hline $\begin{array}{l}\text { Lactobacillus fermentum AGR1487 - cell surface } \\
\text { structures and supernatant }\end{array}$ & $\begin{array}{l}\text { Live and dead AGR1487 decreased TEER across Caco-2 cells } \\
\text { Only live AGR1487 increased the rate of passage of mannitol }\end{array}$ & Sengupta et al., 2015 \\
\hline Lactobacillus rhamnosus GG (live or heat-killed) & Enteral administration accelerated intestinal barrier maturation and induced claudin 3 & Patel et al., 2012 \\
\hline $\begin{array}{l}\text { Lactobacillus helveticus R0052 and } \\
\text { Bifidobacterium longum R0175 }\end{array}$ & Reversed the deficits in intestinal permeability and depressive like behaviors post MI & $\begin{array}{l}\text { Arseneault-Breard } \\
\text { et al., } 2012\end{array}$ \\
\hline Bifidobacterium lactis CNCM I-2494 & $\begin{array}{l}\text { Prevented the increase in intestinal permeability induced by PRS and restored } \\
\text { occludin and JAM-A expressions to control levels }\end{array}$ & Agostini et al., 2012 \\
\hline \multirow[t]{3}{*}{ Bifidobacteria infantis } & $\begin{array}{l}\text { In T84 cells increased TEER, decreased claudin-2, and increased ZO-1 and occludin } \\
\text { expression, associated with enhanced levels of phospho-ERK and decreased levels } \\
\text { of phospho-p38 }\end{array}$ & Ewaschuk et al., 2008 \\
\hline & $\begin{array}{l}\text { Prevented TNF } \alpha \text { and IFN } \gamma \text { induced decrease in TEER and rearrangement of TJ } \\
\text { proteins }\end{array}$ & \\
\hline & $\begin{array}{l}\text { Oral administration acutely reduced colonic permeability in mice whereas long-term } \\
\text { BiCM treatment in IL-10-deficient mice attenuated inflammation, normalized colonic } \\
\text { permeability and decreased colonic and splenic IFN-gamma secretion }\end{array}$ & \\
\hline Bacteroides thetaiotaomicron & $\begin{array}{l}\text { Modulated the expression of genes involved in several important intestinal functions, } \\
\text { including nutrient absorption, mucosal barrier fortification, xenobiotic metabolism, } \\
\text { angiogenesis, and postnatal intestinal maturation }\end{array}$ & Hooper et al., 2001 \\
\hline Escherichia coli Nissle 1917 & Altered the expression and distribution of ZO-2 protein & Zyrek et al., 2007 \\
\hline Escherichia coli Nissle 1917 & $\begin{array}{l}\text { Colonization of GF mice resulted in an up-regulation of ZO-1 in intestinal epithelial } \\
\text { cells at both mRNA and protein levels }\end{array}$ & Ukena et al., 2007 \\
\hline
\end{tabular}

TJ, tight junction; TEER, transepithelial electrical resistance; DSS, dextran sodium sulfate; PRS, partial restraint stress.

potential mechanisms by which dysbiosis contributes to the pathophysiology of disease. Preclinical research points to a role of the gut microbiome in brain function and behavior with a number of potential pathways being investigated. The possibility that these effects might be mediated by alterations in intestinal permeability is supported by converging lines of evidence. This includes evidence linking stress to both compromised barrier function and microbiota disruption with the ensuing systemic inflammation mediating the impact on the expression of neuropsychiatric symptoms (see Figure 2). This hypothesis needs to be elaborated in preclinical and clinical studies to establish the relevance of this proposed mechanism. Such studies will identify whether targeting the epithelial barrier is a viable strategy in managing stress-related disorders, given the established role for the gut microbiota in maintaining barrier function. Indeed, there is growing evidence that certain probiotic strains as well as prebiotics can benefit barrier function, albeit largely in healthy controls or non-psychiatric populations including stress-related GI disorders. However, the success of this strategy will be contingent on identifying sub groups of patients with a compromised epithelial barrier who may be more likely to respond to probiotics with barrier enhancing effects. Alternative approaches such as psychobiotics may target other brain-gut axis pathways independent of any effect on the intestinal barrier. Intervention studies utilizing therapeutic modulation of the gut microbiota or its metabolites to restore "normal" intestinal permeability will may be of benefit in stress-related disorders. As we discussed throughout this review, the impact of a variety of factors implicated in barrier function, such as SCFAs, could also produce their effects at higher centers independently of a compromised intestinal barrier. One clear example of a distinct alternative signaling mechanism between the gut microbiota and the CNS is via the vagus nerve (Bravo et al., 2011). In addition to the disorders mentioned in this review, preclinical evidence suggests that the gut microbiota modulates behaviors associated with neurodevelopmental disorders such as autism spectrum disorder and schizophrenia (Hsiao et al., 2013; Desbonnet et al., 2014; Mayer et al., 2014b). 


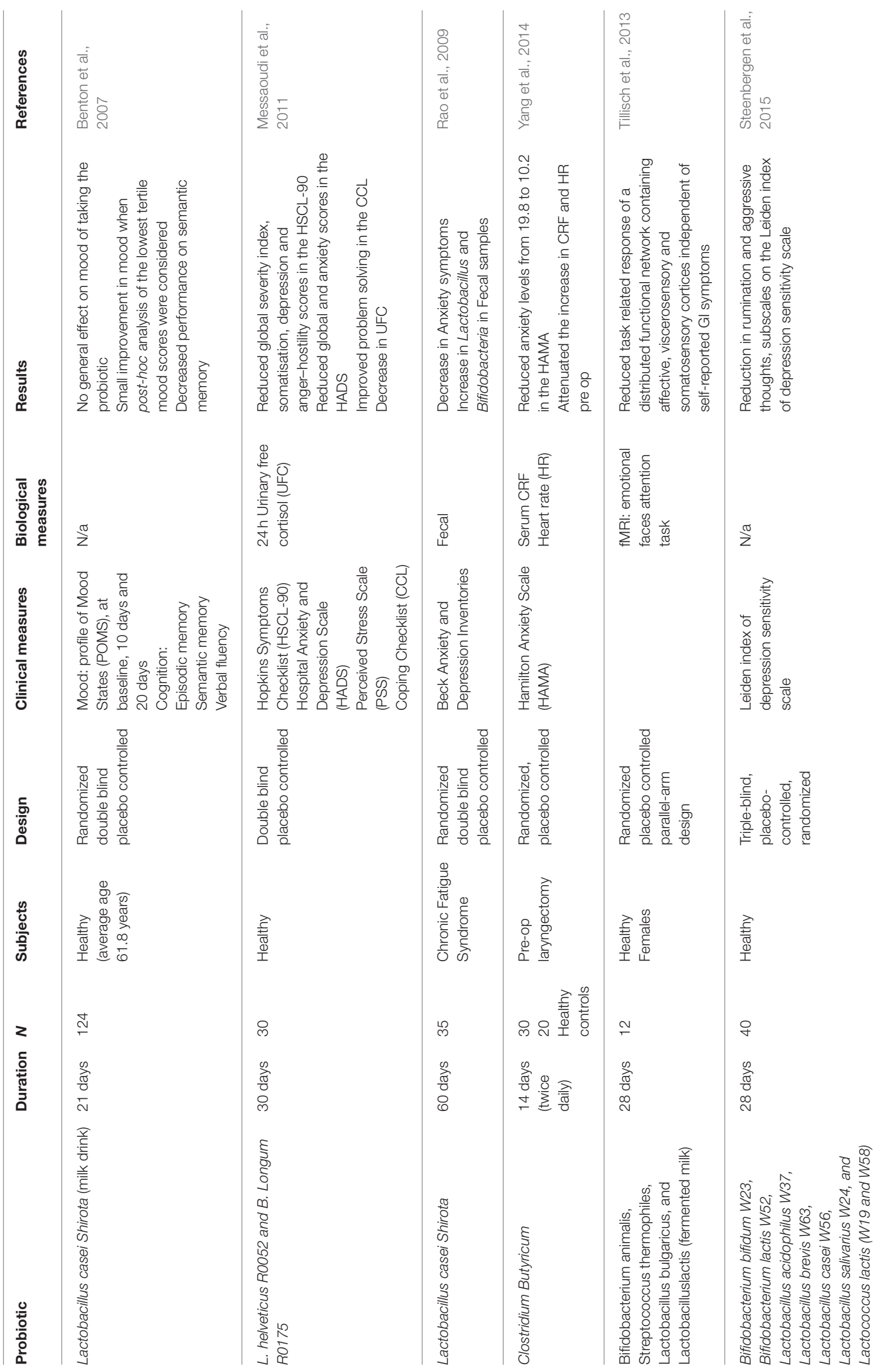




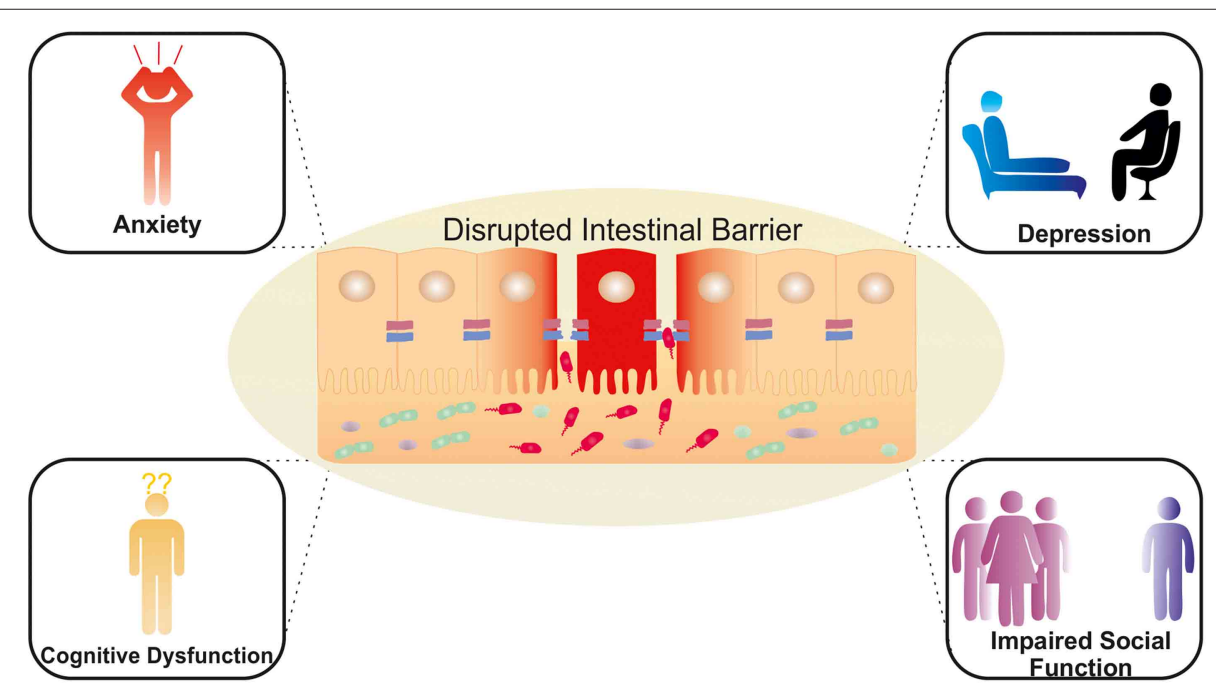

FIGURE 2 | Potential neuropsychiatric consequences of a dysregulated intestinal barrier. Activation of brain-gut-microbiota Axis signaling pathways via a compromised intestinal barrier with potential effects on mood, anxiety, cognition and social interaction.

However, the clinical implications and the role of the intestinal barrier have yet to be fully established (Julio-Pieper et al., 2014; Mayer et al., 2015). We acknowledge that the associations between a "leaky gut" and stress-related psychiatric disorders are not without controversy and the narrative surrounding the impact of the gut microbiome on the CNS requires further development, both mechanistically and with respect to translation from promising preclinical findings to solid clinical relevance. Integrating these important observations within the theoretical framework of this review may provide the impetus to clearly establish the clinical significance of these intriguing concepts and the potential inherent in this field supports further investment and concerted efforts in this area. This success of this investigation holds promise for novel treatment options and preventative plans to support good mental health and to counteract the negative consequences of excessive stress loads.

\section{References}

Abreu, M. T. (2010). Toll-like receptor signalling in the intestinal epithelium: how bacterial recognition shapes intestinal function. Nat. Rev. Immunol. 11, 215-215. doi: $10.1038 /$ nri2728

Agostini, S., Goubern, M., Tondereau, V., Salvador-Cartier, C., Bezirard, V., Lévèque, M., et al. (2012). A marketed fermented dairy product containing Bifidobacterium lactis CNCM I-2494 suppresses gut hypersensitivity and colonic barrier disruption induced by acute stress in rats. Neurogastroenterol. Motil. 24, 376-e172. doi: 10.1111/j.1365-2982.2011.01865.x

Ait-Belgnaoui, A., Bradesi, S., Fioramonti, J., Theodorou, V., and Bueno, L. (2005). Acute stress-induced hypersensitivity to colonic distension depends upon increase in paracellular permeability: role of myosin light chain kinase. Pain 113, 141-147. doi: 10.1016/j.pain.2004.10.002

Ait-Belgnaoui, A., Colom, A., Braniste, V., Ramalho, L., Marrot, A., Cartier, C., et al. (2014). Probiotic gut effect prevents the chronic psychological stressinduced brain activity abnormality in mice. Neurogastroenterol. Motil. 26, 510-520. doi: 10.1111/nmo.12295

\section{Acknowledgments}

We apologize to colleagues whose work we were unable to cite due to space constraints. The APC Microbiome Institute is funded by Science Foundation Ireland (SFI). This publication has emanated from research conducted with the financial support of Science Foundation Ireland (SFI) under Grant Number $\mathrm{SFI} / 12 / \mathrm{RC} / 2273$. The authors and their work were also supported by the Health Research Board (HRB) through Health Research Awards (grants no HRA_POR/2011/23; TD, JC, and GC, HRA_POR/2012/32; JC, TD, and HRA-POR-2-14-647: GC, TD) and through EU GRANT 613979 (MYNEWGUT FP7-KBBE2013-7). The Centre has conducted studies in collaboration with several companies including GSK, Pfizer, Wyeth and Mead Johnson. GC is supported by a NARSAD Young Investigator Grant from the Brain and Behavior Research Foundation (Grant Number 20771).
Ait-Belgnaoui, A., Durand, H., Cartier, C., Chaumaz, G., Eutamene, H., Ferrier, L., et al. (2012). Prevention of gut leakiness by a probiotic treatment leads to attenuated HPA response to an acute psychological stress in rats. Psychoneuroendocrinology 37, 1885-1895. doi: 10.1016/j.psyneuen.2012.03.024

Akbaraly, T. N., Brunner, E. J., Ferrie, J. E., Marmot, M. G., Kivimaki, M., and Singh-Manoux, A. (2009). Dietary pattern and depressive symptoms in middle age. Br. J. Psychiatry 195, 408-413. doi: 10.1192/bjp.bp.108.058925

Akira, S., and Takeda, K. (2004). Toll-like receptor signalling. Nat. Rev. Immunol. 4, 499-511. doi: 10.1038/nri1391

Alonso, C., Guilarte, M., Vicario, M., Ramos, L., Rezzi, S., Martínez, C., et al. (2012). Acute experimental stress evokes a differential gender-determined increase in human intestinal macromolecular permeability. Neurogastroenterol. Motil. 24, e348-e349. doi: 10.1111/j.1365-2982.2012.01928.x

Ammori, B. J., Fitzgerald, P., Hawkey, P., and McMahon, M. J. (2003). The early increase in intestinal permeability and systemic endotoxin exposure in patients with severe acute pancreatitis is not associated with systemic bacterial translocation: molecular investigation of microbial DNA in the blood. Pancreas 26, 18-22. doi: 10.1097/00006676-200301000-00004 
Anderson, A. D., Jain, P. K., Fleming, S., Poon, P., Mitchell, C. J., and MacFie, J. (2004). Evaluation of a triple sugar test of colonic permeability in humans. Acta Physiol. Scand. 182, 171-177. doi: 10.1111/j.1365-201X.2004.01347.x

Anderson, R. C., Cookson, A. L., McNabb, W. C., Kelly, W. J., and Roy, N. C. (2010a). Lactobacillus plantarum DSM 2648 is a potential probiotic that enhances intestinal barrier function. FEMS Microbiol. Lett. 309, 184-192. doi: 10.1111/j.1574-6968.2010.02038.x

Anderson, R. C., Cookson, A. L., McNabb, W. C., Park, Z., McCann, M. J., Kelly, W. J., et al. (2010b). Lactobacillus plantarum MB452 enhances the function of the intestinal barrier by increasing the expression levels of genes involved in tight junction formation. BMC Microbiol. 10:316. doi: 10.1186/1471-2180-10-316

Antoni, L., Nuding, S., Wehkamp, J., and Stange, E. F. (2014). Intestinal barrier in inflammatory bowel disease. World J. Gastroenterol. 20, 1165-1179. doi: 10.3748/wjg.v20.i5.1165

Arseneault-Bréard, J., Rondeau, I., Gilbert, K., Girard, S. A., Tompkins, T. A., Godbout, R., et al. (2012). Combination of Lactobacillus helveticus R0052 and Bifidobacterium longum R0175 reduces post-myocardial infarction depression symptoms and restores intestinal permeability in a rat model. Br. J. Nutr. 107, 1793-1799. doi: 10.1017/S0007114511005137

Artis, D. (2008). Epithelial-cell recognition of commensal bacteria and maintenance of immune homeostasis in the gut. Nat. Rev. Immunol. 8, 411-420. doi: $10.1038 /$ nri2316

Baes, C. V., Martins, C. M., Tofoli, S. M., and Juruena, M. F. (2014). Early life stress in depressive patients: HPA axis response to GR and MR agonist. Front. Psychiatry 5:2. doi: 10.3389/fpsyt.2014.00002

Bailey, M. T., and Coe, C. L. (1999). Maternal separation disrupts the integrity of the intestinal microflora in infant rhesus monkeys. Dev. Psychobiol. 35, $146-155$.

Bailey, M. T., Dowd, S. E., Galley, J. D., Hufnagle, A. R., Allen, R. G., and Lyte, M. (2011). Exposure to a social stressor alters the structure of the intestinal microbiota: implications for stressor-induced immunomodulation. Brain Behav. Immun. 25, 397-407. doi: 10.1016/j.bbi.2010.10.023

Barrett, E., Kerr, C., Murphy, K., O’Sullivan, O., Ryan, C. A., Dempsey, E. M., et al. (2013). The individual-specific and diverse nature of the preterm infant microbiota. Arch. Dis. Child. Fetal Neonatal Ed. 98, F334-F340. doi: 10.1136/archdischild-2012-303035

Bauer, H. C., Krizbai, I. A., Bauer, H., and Traweger, A. (2014). "You shall not pass"-tight junctions of the blood brain barrier. Front. Neurosci. 8:392. doi: 10.3389/fnins.2014.00392

Benton, D., Williams, C., and Brown, A. (2007). Impact of consuming a milk drink containing a probiotic on mood and cognition. Eur. J. Clin. Nutr. 61, 355-361. doi: 10.1038/sj.ejcn. 1602546

Bercik, P., and Collins, S. M. (2014). The effects of inflammation, infection and antibiotics on the microbiota-gut-brain axis. Adv. Exp. Med. Biol. 817, 279-289. doi: 10.1007/978-1-4939-0897-4_13

Berger, M., Gray, J. A., and Roth, B. L. (2009). The expanded biology of serotonin. Annu. Rev. Med. 60, 355-366. doi: 10.1146/annurev.med.60.042307.110802

Berkes, J., Viswanathan, V. K., Savkovic, S. D., and Hecht, G. (2003). Intestinal epithelial responses to enteric pathogens: effects on the tight junction barrier, ion transport, and inflammation. Gut 52, 439-451. doi: 10.1136/gut.52.3.439

Bindels, L. B., Delzenne, N. M., Cani, P. D., and Walter, J. (2015). Towards a more comprehensive concept for prebiotics. Nat. Rev. Gastroenterol. Hepatol. 12, 303-310. doi: 10.1038/nrgastro.2015.47

Bischoff, S. C., Barbara, G., Buurman, W., Ockhuizen, T., Schulzke, J. D., Serino, M., et al. (2014). Intestinal permeability-a new target for disease prevention and therapy. BMC Gastroenterol. 14:189. doi: 10.1186/s12876-014-0189-7

Blankstein, U., Chen, J., Diamant, N. E., and Davis, K. D. (2010). Altered brain structure in irritable bowel syndrome: potential contributions of preexisting and disease-driven factors. Gastroenterology 138, 1783-1789. doi: 10.1053/j.gastro.2009.12.043

Bohórquez, D. V., Shahid, R. A., Erdmann, A., Kreger, A. M., Wang, Y., Calakos, N., et al. (2015). Neuroepithelial circuit formed by innervation of sensory enteroendocrine cells. J. Clin. Invest. 125, 782-786. doi: 10.1172/JCI78361

Bonfrate, L., Tack, J., Grattagliano, I., Cuomo, R., and Portincasa, P. (2013). Microbiota in health and irritable bowel syndrome: current knowledge, perspectives and therapeutic options. Scand. J. Gastroenterol. 48, 995-1009. doi: $10.3109 / 00365521.2013 .799220$
Borre, Y. E., O'Keeffe, G. W., Clarke, G., Stanton, C., Dinan, T. G., and Cryan, J. F. (2014). Microbiota and neurodevelopmental windows: implications for brain disorders. Trends Mol. Med. 20, 509-518. doi: 10.1016/j.molmed.2014.05.002

Braniste, V., Al-Asmakh, M., Kowal, C., Anuar, F., Abbaspour, A., Tóth, M., et al. (2014). The gut microbiota influences blood-brain barrier permeability in mice. Sci. Transl. Med. 6, 263ra158. doi: 10.1126/scitranslmed.3009759

Bravo, J. A., Forsythe, P., Chew, M. V., Escaravage, E., Savignac, H. M., Dinan, T. G., et al. (2011). Ingestion of Lactobacillus strain regulates emotional behavior and central GABA receptor expression in a mouse via the vagus nerve. Proc. Natl. Acad. Sci. U.S.A. 108, 16050-16055. doi: 10.1073/pnas.11029 99108

Bron, P. A., van Baarlen, P., and Kleerebezem, M. (2012). Emerging molecular insights into the interaction between probiotics and the host intestinal mucosa. Nat. Rev. Microbiol. 10, 66-78. doi: 10.1038/nrmicro2690

Camilleri, M., Lasch, K., and Zhou, W. (2012). Irritable bowel syndrome: methods, mechanisms, and pathophysiology. The confluence of increased permeability, inflammation, and pain in irritable bowel syndrome. Am. J. Physiol. Gastrointest. Liver Physiol. 303, G775-G785. doi: 10.1152/ajpgi.00155.2012

Cani, P. D., Bibiloni, R., Knauf, C., Waget, A., Neyrinck, A. M., Delzenne, N. M., et al. (2008). Changes in gut microbiota control metabolic endotoxemiainduced inflammation in high-fat diet-induced obesity and diabetes in mice. Diabetes 57, 1470-1481. doi: 10.2337/db07-1403

Cani, P. D., Possemiers, S., Van de Wiele, T., Guiot, Y., Everard, A., Rottier, O., et al. (2009). Changes in gut microbiota control inflammation in obese mice through a mechanism involving GLP-2-driven improvement of gut permeability. Gut 58, 1091-1103. doi: 10.1136/gut.2008.165886

Cario, E., Gerken, G., and Podolsky, D. (2004). Toll-like receptor 2 controls mucosal inflammation by regulating epithelial barrier function. Gastroenerology 127, 224-238. doi: 10.1053/j.gastro.2004.04.015

Carroll, I. M., Ringel-Kulka, T., Keku, T. O., Chang, Y.-H., Packey, C. D., Sartor, R. B., et al. (2011). Molecular analysis of the luminal- and mucosalassociated intestinal microbiota in diarrhea-predominant irritable bowel syndrome. Am. J. Physiol. Gastrointest. Liver Physiol. 301, G799-G807. doi: 10.1152/ajpgi.00154.2011

Casen, C., Vebo, H. C., Sekelja, M., Hegge, F. T., Karlsson, M. K., Ciemniejewska, E., et al. (2015). Deviations in human gut microbiota: a novel diagnostic test for determining dysbiosis in patients with IBS or IBD. Aliment. Pharmacol. Ther. 42, 71-83. doi: 10.1111/apt.13236

Cichon, C., Sabharwal, H., Rüter, C., and Schmidt, M. A. (2014). MicroRNAs regulate tight junction proteins and modulate epithelial/endothelial barrier functions. Tissue Barriers 2:e944446. doi: 10.4161/21688362.2014. 944446

Claes, I. J., Lebeer, S., Shen, C., Verhoeven, T. L., Dilissen, E., De Hertogh, G. et al. (2010). Impact of lipoteichoic acid modification on the performance of the probiotic Lactobacillus rhamnosus GG in experimental colitis. Clin. Exp. Immunol. 162, 306-314. doi: 10.1111/j.1365-2249.2010.04228.x

Claesson, M. J., Cusack, S., O'Sullivan, O., Greene-Diniz, R., de Weerd, H., Flannery, E., et al. (2011). Composition, variability, and temporal stability of the intestinal microbiota of the elderly. Proc. Natl. Acad. Sci. U.S.A. 108(Suppl. 1), 4586-4591. doi: 10.1073/pnas.1000097107

Claesson, M. J., Jeffery, I. B., Conde, S., Power, S. E., O’Connor, E. M., Cusack, S., et al. (2012). Gut microbiota composition correlates with diet and health in the elderly. Nature 488, 178-184. doi: 10.1038/nature11319

Clarke, G., Cryan, J. F., Dinan, T. G., and Quigley, E. M. (2012). Review article: probiotics for the treatment of irritable bowel syndrome-focus on lactic acid bacteria. Aliment. Pharmacol. Ther. 35, 403-413. doi: 10.1111/j.13652036.2011.04965.x

Clarke, G., Grenham, S., Scully, P., Fitzgerald, P., Moloney, R. D., Shanahan, F., et al. (2013). The microbiome-gut-brain axis during early life regulates the hippocampal serotonergic system in a sex-dependent manner. Mol. Psychiatry 18, 666-673. doi: $10.1038 / \mathrm{mp} .2012 .77$

Collins, S. M. (2014). A role for the gut microbiota in IBS. Nat. Rev. Gastroenterol. Hepatol. 11, 497-505. doi: 10.1038/nrgastro.2014.40

Collins, S. M., and Bercik, P. (2013). Gut microbiota: intestinal bacteria influence brain activity in healthy humans. Nat. Rev. Gastroenterol. Hepatol. 10, 326-327. doi: 10.1038/nrgastro.2013.76

Corridoni, D., Pastorelli, L., Mattioli, B., Locovei, S., Ishikawa, D., Arseneau, K. O., et al. (2012). Probiotic bacteria regulate intestinal epithelial permeability in 
experimental ileitis by a TNF-dependent mechanism. PLoS ONE 7:e42067. doi: 10.1371/journal.pone.0042067

Craig, O. F., and Quigley, E. M. (2010). Bacteria, genetics and irritable bowel syndrome. Expert. Rev. Gastroenterol. Hepatol. 4, 271-276. doi: 10.1586/egh.10.31

Crenn, P., Coudray-Lucas, C., Thuillier, F., Cynober, L., and Messing, B. (2000). Postabsorptive plasma citrulline concentration is a marker of absorptive enterocyte mass and intestinal failure in humans. Gastroenterology 119, 1496-1505. doi: 10.1053/gast.2000.20227

Cryan, J. F., and Dinan, T. G. (2012). Mind-altering microorganisms: the impact of the gut microbiota on brain and behaviour. Nat. Rev. Neurosci. 13, 701-712. doi: $10.1038 / \mathrm{nrn} 3346$

Cryan, J. F., and Dinan, T. G. (2015). Gut microbiota: microbiota and neuroimmune signalling-Metchnikoff to microglia. Nat. Rev. Gastroenterol. Hepatol. 12, 494-496. doi: 10.1038/nrgastro.2015.127

Cummins, A. G., and Thompson, F. M. (2002). Effect of breast milk and weaning on epithelial growth of the small intestine in humans. Gut 51, 748-754. doi: 10.1136/gut.51.5.748

da Silva, S. T., dos Santos, C. A., and Bressan, J. (2013). Intestinal microbiota; relevance to obesity and modulation by prebiotics and probiotics. Nutr. Hosp. 28, 1039-1048. doi: 10.3305/nh.2013.28.4.6525

Da Silva, S., Robbe-Masselot, C., Ait-Belgnaoui, A., Mancuso, A., MercadeLoubière, M., Salvador-Cartier, C., et al. (2014). Stress disrupts intestinal mucus barrier in rats via mucin O-glycosylation shift: prevention by a probiotic treatment. Am. J. Physiol. Gastrointest. Liver Physiol. 307, G420-G429. doi: 10.1152/ajpgi.00290.2013

Daneman, R., and Rescigno, M. (2009). The gut immune barrier and the blood-brain barrier: are they so different? Immunity 31, 722-735. doi: 10.1016/j.immuni.2009.09.012

Daniel, H., Moghaddas Gholami, A., Berry, D., Desmarchelier, C., Hahne, H., Loh, G., et al. (2014). High-fat diet alters gut microbiota physiology in mice. ISME J. 8, 295-308. doi: 10.1038/ismej.2013.155

Dantzer, R., O’Connor, J. C., Freund, G. G., Johnson, R. W., and Kelley, K. W. (2008). From inflammation to sickness and depression: when the immune system subjugates the brain. Nat. Rev. Neurosci. 9, 46-56. doi: 10.1038/ nrn2297

David, L. A., Maurice, C. F., Carmody, R. N., Gootenberg, D. B., Button, J. E., Wolfe, B. E., et al. (2014). Diet rapidly and reproducibly alters the human gut microbiome. Nature 505, 559-563. doi: 10.1038/nature12820

de Magistris, L., Familiari, V., Pascotto, A., Sapone, A., Frolli, A., Iardino, P., et al. (2010). Alterations of the intestinal barrier in patients with autism spectrum disorders and in their first-degree relatives. J. Pediatr. Gastroenterol. Nutr. 51, 418-424. doi: 10.1097/MPG.0b013e3181dcc4a5

De Palma, G., Blennerhassett, P., Lu, J., Deng, Y., Park, A. J., Green, W., et al. (2015). Microbiota and host determinants of behavioural phenotype in maternally separated mice. Nat. Commun. 6:7735. doi: 10.1038/ncomms8735

De Palma, G., Collins, S. M., and Bercik, P. (2014a). The microbiota-gut-brain axis in functional gastrointestinal disorders. Gut Microbes 5, 419-429. doi: 10.4161/gmic. 29417

De Palma, G., Collins, S. M., Bercik, P., and Verdu, E. F. (2014b). The microbiotagut-brain axis in gastrointestinal disorders: stressed bugs, stressed brain or both? J. Physiol. 592, 2989-2997. doi: 10.1113/jphysiol.2014.273995

Derikx, J. P., Blijlevens, N. M., Donnelly, J. P., Fujii, H., Kanda, T., van Bijnen, A. A., et al. (2009). Loss of enterocyte mass is accompanied by diminished turnover of enterocytes after myeloablative therapy in haematopoietic stem-cell transplant recipients. Ann. Oncol. 20, 337-342. doi: 10.1093/annonc/mdn579

Derrien, M., and van Hylckama Vlieg, J. E. (2015). Fate, activity, and impact of ingested bacteria within the human gut microbiota. Trends Microbiol. 23, 354-366. doi: 10.1016/j.tim.2015.03.002

Desbonnet, L., Clarke, G., Shanahan, F., Dinan, T. G., and Cryan, J. F. (2014). Microbiota is essential for social development in the mouse. Mol. Psychiatry 19, 146-148. doi: 10.1038/mp.2013.65

Desbonnet, L., Garrett, L., Clarke, G., Bienenstock, J., and Dinan, T. G. (2008). The probiotic Bifidobacteria infantis: an assessment of potential antidepressant properties in the rat. J. Psychiatr. Res. 43, 164-174. doi: 10.1016/j.jpsychires.2008.03.009

Dethlefsen, L., and Relman, D. A. (2011). Incomplete recovery and individualized responses of the human distal gut microbiota to repeated antibiotic perturbation. Proc. Natl. Acad. Sci. U.S.A. 108(Suppl. 1), 4554-4561. doi: $10.1073 /$ pnas. 1000087107

Dethlefsen, L., McFall-Ngai, M., and Relman, D. A. (2007). An ecological and evolutionary perspective on human-microbe mutualism and disease. Nature 449, 811-818. doi: 10.1038/nature06245

Dewulf, E. M., Cani, P. D., Claus, S. P., Fuentes, S., Puylaert, P. G., Neyrinck, A. M., et al. (2013). Insight into the prebiotic concept: lessons from an exploratory, double blind intervention study with inulin-type fructans in obese women. Gut 62, 1112-1121. doi: 10.1136/gutjnl-2012-303304

Dickerson, F. B., Stallings, C., Origoni, A., Katsafanas, E., Savage, C. L., Schweinfurth, L. A., et al. (2014). Effect of probiotic supplementation on schizophrenia symptoms and association with gastrointestinal functioning: a randomized, placebo-controlled trial. Prim. Care Companion CNS Disord. 16:PCC.13m01579. doi: 10.4088/PCC.13m01579

Didari, T., Mozaffari, S., Nikfar, S., and Abdollahi, M. (2015). Effectiveness of probiotics in irritable bowel syndrome: updated systematic review with meta-analysis. World J. Gastroenterol. 21, 3072-3084. doi: 10.3748/wjg.v21.i10. 3072

Dinan, T. G., and Cryan, J. F. (2013). Melancholic microbes: a link between gut microbiota and depression? Neurogastroenterol. Motil. 25, 713-719. doi: $10.1111 /$ nmo. 12198

Dinan, T. G., Stanton, C., and Cryan, J. F. (2013). Psychobiotics: a novel class of psychotropic. Biol. Psychiatry 74, 720-726. doi: 10.1016/j.biopsych.2013. 05.001

Dominguez-Bello, M. G., Costello, E. K., Contreras, M., Magris, M., Hidalgo, G., Fierer, N., et al. (2010). Delivery mode shapes the acquisition and structure of the initial microbiota across multiple body habitats in newborns. Proc. Natl. Acad. Sci. U.S.A. 107, 11971-11975. doi: 10.1073/pnas.1002601107

Doran, K. S., Banerjee, A., Disson, O., and Lecuit, M. (2013). Concepts and mechanisms: crossing host barriers. Cold Spring Harbor Perspect. Med. 3. doi: 10.1101/cshperspect.a010090

Dörfel, M. J., and Huber, O. (2012). Modulation of tight junction structure and function by kinases and phosphatases targeting occludin. J. Biomed. Biotechnol. 2012:807356. doi: 10.1155/2012/807356

Dunlop, S. P., Hebden, J., Campbell, E., Naesdal, J., Olbe, L., Perkins, A. C., et al. (2006). Abnormal intestinal permeability in subgroups of diarrheapredominant irritable bowel syndromes. Am. J. Gastroenterol. 101, 1288-1294. doi: 10.1111/j.1572-0241.2006.00672.x

Eckburg, P. B., Bik, E. M., Bernstein, C. N., Purdom, E., Dethlefsen, L., Sargent, M., et al. (2005). Diversity of the human intestinal microbial flora. Science 308, 1635-1638. doi: 10.1126/science.1110591

El Aidy, S., Kunze, W., Bienenstock, J., and Kleerebezem, M. (2012). The microbiota and the gut-brain axis: insights from the temporal and spatial mucosal alterations during colonisation of the germfree mouse intestine. Benef. Microbes 3, 251-259. doi: 10.3920/BM2012.0042

Elamin, E. E., Masclee, A. A., Dekker, J., Pieters, H.-J., and Jonkers, D. M. (2013). Short-chain fatty acids activate AMP-activated protein kinase and ameliorate ethanol-induced intestinal barrier dysfunction in Caco-2 cell monolayers. J. Nutr. 143, 1872-1881. doi: 10.3945/jn.113.179549

Eutamene, H., and Bueno, L. (2007). Role of probiotics in correcting abnormalities of colonic flora induced by stress. Gut 56, 1495-1497. doi: 10.1136/gut.2007.124040

Everard, A., Belzer, C., Geurts, L., Ouwerkerk, J. P., Druart, C., Bindels, L. B., et al. (2013). Cross-talk between Akkermansia muciniphila and intestinal epithelium controls diet-induced obesity. Proc. Natl. Acad. Sci. U.S.A. 110, 9066-9071. doi: 10.1073/pnas.1219451110

Everard, A., Lazarevic, V., Derrien, M., Girard, M., Muccioli, G. G., Neyrinck, A. M., et al. (2011). Responses of gut microbiota and glucose and lipid metabolism to prebiotics in genetic obese and diet-induced leptin-resistant mice. Diabetes 60, 2775-2786. doi: 10.2337/db11-0227

Ewaschuk, J. B., Diaz, H., Meddings, L., Diederichs, B., Dmytrash, A., Backer, J., et al. (2008). Secreted bioactive factors from Bifidobacterium infantis enhance epithelial cell barrier function. Am. J. Physiol. Gastrointest. Liver Physiol. 295, G1025-G1034. doi: 10.1152/ajpgi.90227.2008

Ewaschuk, J., Endersby, R., Thiel, D., Diaz, H., Backer, J., Ma, M., et al. (2007). Probiotic bacteria prevent hepatic damage and maintain colonic barrier function in a mouse model of sepsis. Hepatology 46, 841-850. doi: 10.1002/hep. 21750 
Farhadi, A., Banan, A., Fields, J., and Keshavarzian, A. (2003). Intestinal barrier: an interface between health and disease. J. Gastroenterol. Hepatol. 18, 479-497. doi: 10.1046/j.1440-1746.2003.03032.x

Fasano, A. (2011). Zonulin and ist regulation of intestinal barrier function: the biological door to inflammation, autoimmunity, and cancer. Physiol. Rev. 91, 151-175. doi: 10.1152/physrev.00003.2008

Fasano, A., and Shea-Donohue, T. (2005). Mechanisms of disease: the role of intestinal barrier function in the pathogenesis of gastrointestinal autoimmune diseases. Nat. Clin. Pract. Gastroenterol. Hepatol. 2, 416-422. doi: 10.1038/ncpgasthep0259

Ferrier, L., Mazelin, L., Cenac, N., Desreumaux, P., Janin, A., Emilie, D., et al. (2003). Stress-induced disruption of colonic epithelial barrier: role of interferon-gamma and myosin light chain kinase in mice. Gastroenterology 125, 795-804. doi: 10.1016/S0016-5085(03)01057-6

Flynn, A. N., and Buret, A. G. (2008). Tight junctional disruption and apoptosis in an in vitro model of Citrobacter rodentium infection. Microb. Pathog. 45, 98-104. doi: 10.1016/j.micpath.2007.12.004

Franzosa, E. A., Morgan, X. C., Segata, N., Waldron, L., Reyes, J., Earl, A. M., et al. (2014). Relating the metatranscriptome and metagenome of the human gut. Proc. Natl. Acad. Sci. U.S.A. 111, E2329-E2338. doi: 10.1073/pnas.1319284111

Frasca, D., and Blomberg, B. B. (2015). Inflammaging decreases adaptive and innate immune responses in mice and humans. Biogerontology. doi: 10.1007/s10522-015-9578-8. [Epub ahead of print].

Frost, G., Sleeth, M. L., Sahuri-Arisoylu, M., Lizarbe, B., Cerdan, S., Brody, L., et al. (2014). The short-chain fatty acid acetate reduces appetite via a central homeostatic mechanism. Nat. Commun. 5:3611. doi: 10.1038/ncomms4611

Fujimura, K. E., Slusher, N. A., Cabana, M. D., and Lynch, S. V. (2010). Role of the gut microbiota in defining human health. Expert Rev. Anti Infect. Ther. 8, 435-454. doi: 10.1586/eri.10.14

Galley, J. D., Nelson, M. C., Yu, Z., Dowd, S. E., Walter, J., Kumar, P. S., et al. (2014a). Exposure to a social stressor disrupts the community structure of the colonic mucosa-associated microbiota. BMC Microbiol. 14:189. doi: 10.1186/1471-2180-14-189

Galley, J. D., Yu, Z., Kumar, P., Dowd, S. E., Lyte, M., and Bailey, M. T. (2014b). The structures of the colonic mucosa-associated and luminal microbial communities are distinct and differentially affected by a prolonged murine stressor. Gut Microbes 5, 748-760. doi: 10.4161/19490976.2014.972241

Garg, A. X., Marshall, J., Salvadori, M., Thiessen-Philbrook, H. R., Macnab, J., Suri, R. S., et al. (2006). A gradient of acute gastroenteritis was characterized, to assess risk of long-term health sequelae after drinking bacterial-contaminated water. J. Clin. Epidemiol. 59, 421-428. doi: 10.1016/j.jclinepi.2005. 08.014

Gerova, V. A., Stoynov, S. G., Katsarov, D. S., and Svinarov, D. A. (2011). Increased intestinal permeability in inflammatory bowel diseases assessed by iohexol test. World J. Gastroenterol. 17, 2211-2215. doi: 10.3748/wjg.v17.i17

Ghanim, H., Abuaysheh, S., Sia, C. L., Korzeniewski, K., Chaudhuri, A., FernandezReal, J. M., et al. (2009). Increase in plasma endotoxin concentrations and the expression of toll-like receptors and suppressor of cytokine signaling- 3 in mononuclear cells after a high-fat, high-carbohydrate meal: implications for insulin resistance. Diabetes Care 32, 2281-2287. doi: 10.2337/dc 09-0979

Gibson, G. R. (2004). Fibre and effects on probiotics (the prebiotic concept). Clin. Nutr. Suppl. 1, 25-31. doi: 10.1016/j.clnu.2004.09.005

Greiner, T., and Bäckhed, F. (2011). Effects of the gut microbiota on obesity and glucose homeostasis. Trends Endocrinol. Metab. 22, 117-123. doi: 10.1016/j.tem.2011.01.002

Grenham, S., Clarke, G., Cryan, J. F., and Dinan, T. G. (2011). Brain-gutmicrobe communication in health and disease. Front. Physiol. 2:94. doi: 10.3389/fphys.2011.00094

Grootjans, J., Thuijls, G., Verdam, F., Derikx, J. P., Lenaerts, K., and Buurman, W. A. (2010). Non-invasive assessment of barrier integrity and function of the human gut. World J. Gastrointest. Surg. 2, 61-69. doi: 10.4240/wjgs.v2.i3.61

Groschwitz, K. R., and Hogan, S. P. (2009). Intestinal barrier function: molecular regulation and disease pathogenesis. J. Allergy Clin. Immunol. 124, 3-20. doi: 10.1016/j.jaci.2009.05.038

Guarner, F., Bourdet-Sicard, R., Brandtzaeg, P., Gill, H. S., McGuirk, P., and van Eden, W. (2006). Mechanisms of disease: the hygiene hypothesis revisited. Nat. Clin. Pract. Gastroenterol. Hepatol. 3, 275-284. doi: 10.1038/ncpgasthep0471
Hamilton, M. K., Boudry, G., Lemay, D. G., and Raybould, H. E. (2015). Changes in intestinal barrier function and gut microbiota in high-fat diet fed rats are dynamic and region-dependent. Am. J. Physiol. Gastrointest. Liver Physiol. 308, G840-G851. doi: 10.1152/ajpgi.00029.2015

Hawkins, B. T., and Davis, T. P. (2005). The blood-brain barrier/neurovascular unit in health and disease. Pharmacol. Rev. 57, 173-185. doi: 10.1124/pr.57.2.4

Heim, C., Newport, D. J., Heit, S., Graham, Y. P., Wilcox, M., Bonsall, R., et al. (2000). Pituitary-adrenal and autonomic responses to stress in women after sexual and physical abuse in childhood. JAMA 284, 592-597. doi: 10.1001/jama.284.5.592

Heller, F., Florian, P., Bojarski, C., Richter, J., Christ, M., Hillenbrand, B. et al. (2005). Interleukin-13 is the key effector Th2 cytokine in ulcerative colitis that affects epithelial tight junctions, apoptosis, and cell restitution. Gastroenterology 129, 550-564. doi: 10.1016/j.gastro.2005.05.002

Hidaka, B. H. (2012). Depression as a disease of modernity: explanations for increasing prevalence. J. Affect. Disord. 140, 205-214. doi: 10.1016/j.jad.2011.12.036

Hoffmann, D. E., Fraser, C. M., Palumbo, F. B., Ravel, J., Rothenberg, K., Rowthorn, V., et al. (2013). Science and regulation. Probiotics: finding the right regulatory balance. Science 342, 314-315. doi: 10.1126/science.1244656

Hooper, L. V., Wong, M. H., Thelin, A., Hansson, L., Falk, P. G., and Gordon, J. I. (2001). Molecular analysis of commensal host-microbial relationships in the intestine. Science 291, 881-884. doi: 10.1126/science.291.5505.881

Hopkins, P. A., and Sriskandan, S. (2005). Mammalian Toll-like receptors: to immunity and beyond. Clin. Exp. Immunol. 140, 395-407. doi: 10.1111/j.13652249.2005.02801.x

Hoveyda, N., Heneghan, C., Mahtani, K. R., Perera, R., Roberts, N., and Glasziou, P. (2009). A systematic review and meta-analysis: probiotics in the treatment of irritable bowel syndrome. BMC Gastroenterol. 9:15. doi: 10.1186/1471-23 0X-9-15

Hsiao, E. Y., McBride, S. W., Hsien, S., Sharon, G., Hyde, E. R., McCue, T., et al. (2013). Microbiota modulate behavioral and physiological abnormalities associated with neurodevelopmental disorders. Cell 155, 1451-1463. doi: 10.1016/j.cell.2013.11.024

Hueston, C. M., and Deak, T. (2014). The inflamed axis: the interaction between stress, hormones, and the expression of inflammatory-related genes within key structures comprising the hypothalamic-pituitary-adrenal axis. Physiol. Behav. 124, 77-91. doi: 10.1016/j.physbeh.2013.10.035

Ivanov, A. I., Parkos, C. A., and Nusrat, A. (2010). Cytoskeletal regulation of epithelial barrier function during inflammation. Am. J. Pathol. 177, 512-524. doi: 10.2353/ajpath.2010.100168

Jacka, F. N., Cherbuin, N., Anstey, K. J., and Butterworth, P. (2014). Dietary patterns and depressive symptoms over time: examining the relationships with socioeconomic position, health behaviours and cardiovascular risk. PLOS ONE 9:e87657. doi: 10.1371/journal.pone.0087657

Jacka, F. N., Mykletun, A., Berk, M., Bjelland, I., and Tell, G. S. (2011). The Association Between habitual diet quality and the common mental disorders in community-dwelling adults: the hordaland health study. Psychosom. Med. 73, 483-490. doi: 10.1097/PSY.0b013e318222831a

Jacka, F. N., Pasco, J. A., Mykletun, A., Williams, L. J., Hodge, A. M., O’Reilly, S. L., et al. (2010). Association of Western and traditional diets with depression and anxiety in women. Am. J. Psychiatry 167, 305-311. doi: 10.1176/appi.ajp.2009.09060881

Jakobsson, H. E., Rodríguez-Piñeiro, A. M., Schütte, A., Ermund, A., Boysen, P., Bemark, M., et al. (2015). The composition of the gut microbiota shapes the colon mucus barrier. EMBO Rep. 16, 164-177. doi: 10.15252/embr.201439263

Jašarevic, E., Howerton, C. L., Howard, C. D., and Bale, T. L. (2015a). Alterations in the vaginal microbiome by maternal stress are associated with metabolic reprogramming of the offspring gut and brain. Endocrinology 156, 3265-3276. doi: 10.1210/en.2015-1177

Jašarevic, E., Rodgers, A. B., and Bale, T. L. (2015b). A novel role for maternal stress and microbial transmission in early life programming and neurodevelopment. Neurobiol. Stress 1, 81-88. doi: 10.1016/j.ynstr.2014.10.005

Jeffery, I. B., Claesson, M. J., O’Toole, P. W., and Shanahan, F. (2012a). Categorization of the gut microbiota: enterotypes or gradients? Nat. Rev. Microbiol. 10, 591-592. doi: 10.1038/nrmicro2859

Jeffery, I. B., O’Toole, P. W., Öhman, L., Claesson, M. J., Deane, J., Quigley, E. M., et al. (2012b). An irritable bowel syndrome subtype defined by species-specific 
alterations in faecal microbiota. Gut 61, 997-1006. doi: 10.1136/gutjnl-2011301501

Jeffery, I. B., Quigley, E. M., Öhman, L., Simrén, M., and O’Toole, P. W. (2012c). The microbiota link to irritable bowel syndrome: an emerging story. Gut Microbes 3, 572-576. doi: 10.4161/gmic. 21772

Jiang, H., Ling, Z., Zhang, Y., Mao, H., Ma, Z., Yin, Y., et al. (2015). Altered fecal microbiota composition in patients with major depressive disorder. Brain Behav. Immun. 48, 186-194. doi: 10.1016/j.bbi.2015.03.016

Johansson, M. E. V., Larsson, J. M. H., and Hansson, G. C. (2011). The two mucus layers of colon are organized by the MUC2 mucin, whereas the outer layer is a legislator of host-microbial interactions. Proc. Natl. Acad. Sci. U.S.A. 108, 4659-4665. doi: 10.1073/pnas. 1006451107

Johansson, M. E., Gustafsson, J. K., Holmén-Larsson, J., Jabbar, K. S., Xia, L., Xu, H., et al. (2014). Bacteria penetrate the normally impenetrable inner colon mucus layer in both murine colitis models and patients with ulcerative colitis. Gut 63, 281-291. doi: 10.1136/gutjnl-2012-303207

Julio-Pieper, M., Bravo, J. A., Aliaga, E., and Gotteland, M. (2014). Review article: intestinal barrier dysfunction and central nervous system disordersa controversial association. Aliment. Pharmacol. Ther. 40, 1187-1201. doi: 10.1111/apt.12950

Kalischuk, L. D., Inglis, G. D., and Buret, A. G. (2009). Campylobacter jejuni induces transcellular translocation of commensal bacteria via lipid rafts. Gut Pathog. 1:2. doi: 10.1186/1757-4749-1-2

Karczewski, J., Troost, F. J., Konings, I., Dekker, J., Kleerebezem, M., and Brummer, R. J. (2010). Regulation of human epithelial tight junction proteins by Lactobacillus plantarum in vivo and protective effects on the epithelial barrier. Am. J. Physiol. Gastrointest. Liver Physiol. 298, G851-G859. doi: 10.1152/ajpgi.00327.2009

Kennedy, P. J., Clarke, G., O’Neill, A., Groeger, J. A., Quigley, E. M., Shanahan, F., et al. (2014). Cognitive performance in irritable bowel syndrome: evidence of a stress-related impairment in visuospatial memory. Psychol. Med. 44, 1553-1566. doi: 10.1017/S0033291713002171

Kennedy, P. J., Clarke, G., Quigley, E. M., Groeger, J. A., Dinan, T. G., and Cryan, J. F. (2012). Gut memories: towards a cognitive neurobiology of irritable bowel syndrome. Neurosci. Biobehav. Rev. 36, 310-340. doi: 10.1016/j.neubiorev.2011.07.001

Kéri, S., Szabó, C., and Kelemen, O. (2014). Expression of toll-like receptors in peripheral blood mononuclear cells and response to cognitive-behavioral therapy in major depressive disorder. Brain Behav. Immun. 40, 235-243. doi: 10.1016/j.bbi.2014.03.020

Keszthelyi, D., Troost, F. J., Jonkers, D. M., van Eijk, H. M., Lindsey, P. J., Dekker, J., et al. (2014). Serotonergic reinforcement of intestinal barrier function is impaired in irritable bowel syndrome. Aliment. Pharmacol. Ther. 40, 392-402. doi: 10.1111/apt.12842

Kim, K. A., Gu, W., Lee, I. A., Joh, E. H., and Kim, D. H. (2012). High fat diet-induced gut microbiota exacerbates inflammation and obesity in mice via the TLR4 signaling pathway. PLoS ONE 7:e47713. doi: 10.1371/journal.pone.0047713

Klerman, G. L., and Weissman, M. M. (1989). INcreasing rates of depression. JAMA 261, 2229-2235. doi: 10.1001/jama.1989.034201500 79041

Kozakova, H., Schwarzer, M., Tuckova, L., Srutkova, D., Czarnowska, E., Rosiak, I., et al. (2015). Colonization of germ-free mice with a mixture of three lactobacillus strains enhances the integrity of gut mucosa and ameliorates allergic sensitization. Cell. Mol. Immunol. doi: 10.1038/cmi.2015.09. [Epub ahead of print].

Labus, J. S., Naliboff, B. D., Berman, S. M., Suyenobu, B., Vianna, E. P., Tillisch, K., et al. (2009). Brain networks underlying perceptual habituation to repeated aversive visceral stimuli in patients with irritable bowel syndrome. Neuroimage 47, 952-960. doi: 10.1016/j.neuroimage.2009.05.078

Lamprecht, M., Bogner, S., Schippinger, G., Steinbauer, K., Fankhauser, F., Hallstroem, S., et al. (2012). Probiotic supplementation affects markers of intestinal barrier, oxidation, and inflammation in trained men; a randomized, double-blinded, placebo-controlled trial. J. Int. Soc. Sports Nutr. 9:45. doi: 10.1186/1550-2783-9-45

Laukoetter, M. G., Nava, P., and Nusrat, A. (2008). Role of the intestinal barrier in inflammatory bowel disease. World J. Gastroenterol. 14, 401-407. doi: 10.3748/wjg. 14.401
Leclercq, S., De Saeger, C., Delzenne, N., de Timary, P., and Stärkel, P. (2014a). Role of inflammatory pathways, blood mononuclear cells, and gut-derived bacterial products in alcohol dependence. Biol. Psychiatry 76, 725-733. doi: 10.1016/j.biopsych.2014.02.003

Leclercq, S., Matamoros, S., Cani, P. D., Neyrinck, A. M., Jamar, F., Stärkel, P., et al. (2014b). Intestinal permeability, gut-bacterial dysbiosis, and behavioral markers of alcohol-dependence severity. Proc. Natl. Acad. Sci. U.S.A. 111, E4485-E4493. doi: 10.1073/pnas.1415174111

Lennon, E. M., Maharshak, N., Elloumi, H., Borst, L., Plevy, S. E., and Moeser, A. J. (2013). Early life stress triggers persistent colonic barrier dysfunction and exacerbates colitis in adult IL-10-/- mice. Inflamm. Bowel Dis. 19, 712-719. doi: 10.1097/MIB.0b013e3182802a4e

Lewis, K., Lutgendorff, F., Phan, V., Söderholm, J. D., Sherman, P. M., and McKay, D. M. (2010). Enhanced translocation of bacteria across metabolically stressed epithelia is reduced by butyrate. Inflamm. Bowel Dis. 16, 1138-1148. doi: 10.1002/ibd.21177

Ley, R. E., Lozupone, C. A., Hamady, M., Knight, R., and Gordon, J. I. (2008). Worlds within worlds: evolution of the vertebrate gut microbiota. Nat. Rev. Microbiol. 6, 776-788. doi: 10.1038/nrmicro1978

Logan, A. C., and Katzman, M. (2005). Major depressive disorder: probiotics may be an adjuvant therapy. Med. Hypotheses 64, 533-538. doi: 10.1016/j.mehy.2004.08.019

Louis, N. A., and Lin, P. W. (2009). The intestinal immune barrier. Neoreviews 10, e180-e190. doi: 10.1542/neo.10-4-e180

Löwe, B., Andresen, V., Fraedrich, K., Gappmayer, K., Wegscheider, K., Treszl, A., et al. (2014). Psychological outcome, fatigue, and quality of life after infection with shiga toxin-producing Escherichia coli O104. Clin. Gastroenterol. Hepatol. 12, 1848-1855. doi: 10.1016/j.cgh.2014.02.035

Lozupone, C. A., Stombaugh, J. I., Gordon, J. I., Jansson, J. K., and Knight, R. (2012). Diversity, stability and resilience of the human gut microbiota. Nature 489, 220-230. doi: 10.1038/nature 11550

Lucas, M., Chocano-Bedoya, P., Shulze, M. B., Mirzaei, F., O’Reilly, E. J., Okereke, O. I., et al. (2014). Inflammatory dietary pattern and risk of depression among women. Brain Behav. Immun. 36, 46-53. doi: 10.1016/j.bbi.2013.09.014

Lyte, M., Li, W., Opitz, N., Gaykema, R. P., and Goehler, L. E. (2006). Induction of anxiety-like behavior in mice during the initial stages of infection with the agent of murine colonic hyperplasia Citrobacter rodentium. Physiol. Behav. 89, 350-357. doi: 10.1016/j.physbeh.2006.06.019

Macfabe, D. F. (2012). Short-chain fatty acid fermentation products of the gut microbiome: implications in autism spectrum disorders. Microb. Ecol. Health Dis. 23. doi: 10.3402/mehd.v23i0.19260

MacFabe, D. F., Cain, D. P., Rodriguez-Capote, K., Franklin, A. E., Hoffman, J. E., Boon, F., et al. (2007). Neurobiological effects of intraventricular propionic acid in rats: possible role of short chain fatty acids on the pathogenesis and characteristics of autism spectrum disorders. Behav. Brain Res. 176, 149-169. doi: 10.1016/j.bbr.2006.07.025

Macfarlane, G. T., and Macfarlane, S. (2012). Bacteria, colonic fermentation, and gastrointestinal health. J. AOAC Int. 95, 50-60. doi: 10.5740/jaoacint.SGE_Macfarlane

Madara, J. L. (1998). Regulation of the movement of solutes across tight junctions. Annu. Rev. Physiol. 60, 143-159. doi: 10.1146/annurev.physiol.60. 1.143

Madsen, K. L., Doyle, J. S., Jewell, L. D., Tavernini, M. M., and Fedorak, R. N. (1999). Lactobacillus species prevents colitis in interleukin 10 gene-deficient mice. Gastroenterology 116, 1107-1114. doi: 10.1016/S0016-5085(99)70013-2

Madsen, K., Cornish, A., Soper, P., McKaigney, C., Jijon, H., Yachimec, C., et al. (2001). Probiotic bacteria enhance murine and human intestinal epithelial barrier function. Gastroenterology 121, 580-591. doi: 10.1053/gast.2001. 27224

Maes, M., Kubera, M., and Leunis, J. C. (2008). The gut-brain barrier in major depression: intestinal mucosal dysfunction with an increased translocation of LPS from gram negative enterobacteria (leaky gut) plays a role in the inflammatory pathophysiology of depression. Neuro Endocrinol. Lett. 29, $117-124$.

Maes, M., Kubera, M., Leunis, J. C., and Berk, M. (2012). Increased IgA and IgM responses against gut commensals in chronic depression: further evidence for increased bacterial translocation or leaky gut. J. Affect. Disord. 141, 55-62. doi: 10.1016/j.jad.2012.02.023 
Mangell, P., Nejdfors, P., Wang, M., Ahrné, S., Weström, B., Thorlacius, H., et al. (2002). Lactobacillus plantarum 299v inhibits Escherichia coli-induced intestinal permeability. Dig. Dis. Sci. 47, 511-516. doi: 10.1023/A:10179475 31536

Marchiando, A. M., Graham, W. V., and Turner, J. R. (2010). Epithelial barriers in homeostasis and disease. Annu. Rev. Pathol. 5, 119-144. doi: 10.1146/annurev.pathol.4.110807.092135

Marques, T. M., Wall, R., Ross, R. P., Fitzgerald, G. F., Ryan, C. A., and Stanton, C. (2010). Programming infant gut microbiota: influence of dietary and environmental factors. Curr. Opin. Biotechnol. 21, 149-156. doi: 10.1016/j.copbio.2010.03.020

Marshall, J. K. (2009). Post-infectious irritable bowel syndrome following water contamination. Kidney Int. Suppl. S42-S43. doi: 10.1038/ki.2008.618

Marshall, J. K., Thabane, M., Garg, A. X., Clark, W., Meddings, J., and Collins, S. M. (2004). Intestinal permeability in patients with irritable bowel syndrome after a waterborne outbreak of acute gastroenteritis in Walkerton, Ontario. Aliment. Pharmacol. Ther. 20, 1317-1322. doi: 10.1111/j.1365-2036.2004. 02284.x

Mawdsley, J. E., and Rampton, D. S. (2005). Psychological stress in IBD: new insights into pathogenic and therapeutic implications. Gut 54, 1481-1491. doi: 10.1136/gut.2005.064261

Mawe, G. M., and Hoffman, J. M. (2013). Serotonin signalling in the gut-functions, dysfunctions and therapeutic targets. Nat. Rev. Gastroenterol. Hepatol. 10, 473-486. doi: 10.1038/nrgastro.2013.105

Mayer, E. A., Knight, R., Mazmanian, S. K., and Cryan, J. F. (2014a). Gut microbes and the brain: paradigm shift in neuroscience. J. Neurosci. 34, 15490-15496.

Mayer, E. A., Padua, D., and Tillisch, K. (2014b). Altered brain-gut axis in autism: comorbidity or causative mechanisms? Bioessays 36, 933-939. doi: 10.1002/bies.201400075

Mayer, E. A., Tillisch, K., and Gupta, A. (2015). Gut/brain axis and the microbiota. J. Clin. Invest. 125, 926-938. doi: 10.1172/JCI76304

McCusker, R. H., and Kelley, K. W. (2013). Immune-neural connections: how the immune system's response to infectious agents influences behavior. J. Exp. Biol. 216, 84-98. doi: 10.1242/jeb.073411

McDole, J. R., Wheeler, L. W., McDonald, K. G., Wang, B., Konjufca, V., Knoop, K. A., et al. (2012). Goblet cells deliver luminal antigen to CD103+ dendritic cells in the small intestine. Nature 483, 345-349. doi: 10.1038/nature10863

McMonagle, M. P., Halpenny, M., McCarthy, A., Mortell, A., Manning, F., Kilty, C., et al. (2006). Alpha glutathione S-transferase: a potential marker of ischemiareperfusion injury of the intestine after cardiac surgery? J. Pediatr. Surg. 41, 1526-1531. doi: 10.1016/j.jpedsurg.2006.05.017

McVey Neufeld, K. A., Mao, Y. K., Bienenstock, J., Foster, J. A., and Kunze, W. A. (2013). The microbiome is essential for normal gut intrinsic primary afferent neuron excitability in the mouse. Neurogastroenterol. Motil. 25, 183-e88. doi: 10.1111/nmo.12049

Mennigen, R., and Bruewer, M. (2009). Effect of probiotics on intestinal barrier function. Ann. N.Y. Acad. Sci. 1165, 183-189. doi: 10.1111/j.17496632.2009.04059.x

Mennigen, R., Nolte, K., Rijcken, E., Utech, M., Loeffler, B., Senninger, N., et al. (2009). Probiotic mixture VSL\#3 protects the epithelial barrier by maintaining tight junction protein expression and preventing apoptosis in a murine model of colitis. Am. J. Physiol. Gastrointest. Liver Physiol. 296, G1140-G1149. doi: 10.1152/ajpgi.90534.2008

Messaoudi, M., Lalonde, R., Violle, N., Javelot, H., Desor, D., Nejdi, A., et al. (2011). Assessment of psychotropic-like properties of a probiotic formulation (Lactobacillus helveticus R0052 and Bifidobacterium longum R0175) in rats and human subjects. Br. J. Nutr. 105, 755-764. doi: 10.1017/S00071145100 04319

Mika, A., Greenwood, B. N., Chichlowski, M., Borchert, D., Hulen, K. A., Berg, B. M., et al. (2014). 155. Dietary prebiotics increase Bifidobacterium spp. and Lactobacillus spp. in the gut and promote stress resistance. Brain Behav. Immun. 40(Suppl.), e45. doi: 10.1016/j.bbi.2014.06.175

Mittermaier, C., Dejaco, C., Waldhoer, T., Oefferlbauer-Ernst, A., Miehsler, W., Beier, M., et al. (2004). Impact of depressive mood on relapse in patients with inflammatory bowel disease: a prospective 18-month follow-up study. Psychosom. Med. 66, 79-84. doi: 10.1097/01.PSY.0000106907.24881.F2

Miyauchi, E., Morita, H., and Tanabe, S. (2009). Lactobacillus rhamnosus alleviates intestinal barrier dysfunction in part by increasing expression of zonula occludens-1 and myosin light-chain kinase in vivo. J. Dairy Sci. 92, 2400-2408 doi: $10.3168 /$ jds.2008-1698

Mogensen, T. H. (2009). Pathogen recognition and inflammatory signaling in innate immune defenses. Clin. Microbiol. Rev. 22, 240-273. doi: 10.1128/CMR.00046-08

Moloney, R. D., Desbonnet, L., Clarke, G., Dinan, T. G., and Cryan, J. F. (2014). The microbiome: stress, health and disease. Mamm. Genome 25, 49-74. doi: 10.1007/s00335-013-9488-5

Montalto, M., Maggiano, N., Ricci, R., Curigliano, V., Santoro, L., Di Nicuolo, F., et al. (2004). Lactobacillus acidophilus protects tight junctions from aspirin damage in HT-29 cells. Digestion 69, 225-228. doi: 10.1159/000079152

Montgomery, R. K., Mulberg, A. E., and Grand, R. J. (1999). Development of the human gastrointestinal tract: twenty years of progress. Gastroenterology 116, 702-731. doi: 10.1016/S0016-5085(99)70193-9

Moorthy, G., Murali, M. R., and Devaraj, S. N. (2009). Lactobacilli facilitate maintenance of intestinal membrane integrity during Shigella dysenteriae 1 infection in rats. Nutrition 25, 350-358. doi: 10.1016/j.nut.2008.09.004

Moreira, A. P., Texeira, T. F., Ferreira, A. B., Peluzio Mdo, C., and Alfenas Rde, C. (2012). Influence of a high-fat diet on gut microbiota, intestinal permeability and metabolic endotoxaemia. Br. J. Nutr. 108, 801-809. doi: 10.1017/S0007114512001213

Moussaoui, N., Braniste, V., Ait-Belgnaoui, A., Gabanou, M., Sekkal, S., Olier, M., et al. (2014). Changes in intestinal glucocorticoid sensitivity in early life shape the risk of epithelial barrier defect in maternal-deprived rats. PLoS ONE 9:e88382. doi: 10.1371/journal.pone.0088382

Moyano-Porcile, V., Olavarría-Ramírez, L., Gonzalez-Arancibia, C., Bravo, J. A., and Julio-Pieper, M. (2015). Short-term effects of Poly(I:C) on gut permeability. Pharmacol. Res. doi: 10.1016/j.phrs.2015.06.016. [Epub ahead of print].

Mujagic, Z., Ludidi, S., Keszthelyi, D., Hesselink, M. A., Kruimel, J. W., Lenaerts, K., et al. (2014). Small intestinal permeability is increased in diarrhoea predominant IBS, while alterations in gastroduodenal permeability in all IBS subtypes are largely attributable to confounders. Aliment. Pharmacol. Ther. 40, 288-297. doi: 10.1111/apt.12829

Naseribafrouei, A., Hestad, K., Avershina, E., Sekelja, M., Linløkken, A., Wilson, R., et al. (2014). Correlation between the human fecal microbiota and depression. Neurogastroenterol. Motil. 26, 1155-1162. doi: 10.1111/nmo.12378

Nicholson, J. K., Holmes, E., and Wilson, I. D. (2005). Gut microorganisms, mammalian metabolism and personalized health care. Nat. Rev. Microbiol. 3, 431-438. doi: 10.1038/nrmicro1152

Ogbonnaya, E. S., Clarke, G., Shanahan, F., Dinan, T. G., Cryan, J. F., and O'Leary, O. F. (2015). Adult hippocampal neurogenesis is regulated by the microbiome. Biol. Psychiatry 78, e7-e9. doi: 10.1016/j.biopsych.2014.12.023

O'Hara, A. M., and Shanahan, F. (2006). The gut flora as a forgotten organ. EMBO Rep. 7, 688-693. doi: 10.1038/sj.embor.7400731

Ohland, C. L., and Macnaughton, W. K. (2010). Probiotic bacteria and intestinal epithelial barrier function. Am. J. Physiol. Gastrointest. Liver Physiol. 298, G807-G819. doi: 10.1152/ajpgi.00243.2009

Olle, B. (2013). Medicines from microbiota. Nat. Biotechnol. 31, 309-315. doi: $10.1038 /$ nbt.2548

O’Mahony, L., McCarthy, J., Kelly, P., Hurley, G., Luo, F., Chen, K., et al. (2005). Lactobacillus and bifidobacterium in irritable bowel syndrome: symptom responses and relationship to cytokine profiles. Gastroenterology 128, 541-551. doi: 10.1053/j.gastro.2004.11.050

O'Mahony, S. M., Clarke, G., Borre, Y. E., Dinan, T. G., and Cryan, J. F. (2015). Serotonin, tryptophan metabolism and the brain-gut-microbiome axis. Behav. Brain Res. 277, 32-48. doi: 10.1016/j.bbr.2014.07.027

O’Mahony, S. M., Marchesi, J. R., Scully, P., Codling, C., Ceolho, A.-M., Quigley, E. M. M., et al. (2009). Early life stress alters behavior, immunity, and microbiota in rats: implications for irritable bowel syndrome and psychiatric illnesses. Biol. Psychiatry 65, 263-267. doi: 10.1016/j.biopsych.2008. 06.026

Orel, R., and Kamhi Trop, T. (2014). Intestinal microbiota, probiotics and prebiotics in inflammatory bowel disease. World J. Gastroenterol. 20, 11505-11524. doi: 10.3748/wjg.v20.i33.11505

Ortiz-Lucas, M., Tobías, A., Saz, P., and Sebastián, J. J. (2013). Effect of probiotic species on irritable bowel syndrome symptoms: a bring up to date meta-analysis. Rev. Esp. Enferm. Dig. 105, 19-36. doi: 10.4321/S113001082013000100005 
O'Toole, P. W. (2012). Changes in the intestinal microbiota from adulthood through to old age. Clin. Microbiol. Infect 18(Suppl. 4), 44-46. doi: 10.1111/j.1469-0691.2012.03867.x

Overman, E. L., Rivier, J. E., and Moeser, A. J. (2012). CRF induces intestinal epithelial barrier injury via the release of mast cell proteases and TNF-alpha. PLoS ONE 7:e39935. doi: 10.1371/journal.pone.0039935

Paesold, G., Guiney, D. G., Eckmann, L., and Kagnoff, M. F. (2002). Genes in the Salmonella pathogenicity island 2 and the Salmonella virulence plasmid are essential for Salmonella-induced apoptosis in intestinal epithelial cells. Cell. Microbiol. 4, 771-781. doi: 10.1046/j.1462-5822.2002.00233.x

Pålsson-McDermott, E. M., and O'Neill, L. A. (2007). Building an immune system from nine domains. Biochem. Soc. Trans. 35, 1437-1444. doi: 10.1042/BST0351437

Park, A. J., Collins, J., Blennerhassett, P. A., Ghia, J. E., Verdu, E. F., Bercik, P., et al. (2013). Altered colonic function and microbiota profile in a mouse model of chronic depression. Neurogastroenterol. Motil. 25, 733-e575. doi: 10.1111/nmo.12153

Pasternak, B. A., D’Mello, S., Jurickova, I. I., Han, X., Willson, T., Flick, L., et al. (2010). Lipopolysaccharide exposure is linked to activation of the acute phase response and growth failure in pediatric Crohn's disease and murine colitis. Inflamm. Bowel Dis. 16, 856-869. doi: 10.1002/ibd.21132

Patel, R. M., Myers, L. S., Kurundkar, A. R., Maheshwari, A., Nusrat, A., and Lin, P. W. (2012). Probiotic bacteria induce maturation of intestinal claudin 3 expression and barrier function. Am. J. Pathol. 180, 626-635. doi: 10.1016/j.ajpath.2011.10.025

Penders, J., Thijs, C., Vink, C., Stelma, F. F., Snijders, B., Kummeling, I., et al. (2006). Factors influencing the composition of the intestinal microbiota in early infancy. Pediatrics 118, 511-521. doi: 10.1542/peds.2005-2824

Peng, L., He, Z., Chen, W., Holzman, I. R., and Lin, J. (2007). Effects of butyrate on intestinal barrier function in a Caco-2 cell monolayer model of intestinal barrier. Pediatr. Res. 61, 37-41. doi: 10.1203/01.pdr.0000250014.92242.f3

Peng, L., Li, Z. R., Green, R. S., Holzman, I. R., and Lin, J. (2009). Butyrate enhances the intestinal barrier by facilitating tight junction assembly via activation of AMP-activated protein kinase in Caco-2 cell monolayers. J. Nutr. 139, 1619-1625. doi: 10.3945/jn.109.104638

Persaud, R., Azad, M. B., Konya, T., Guttman, D. S., Chari, R. S., Sears, M. R., et al. (2014). Impact of perinatal antibiotic exposure on the infant gut microbiota at one year of age. Allergy Asthma Clin. Immunol. 10, A31. doi: 10.1186/1710-1492-10-S1-A31

Petschow, B., Doré, J., Hibberd, P., Dinan, T., Reid, G., Blaser, M., et al. (2013). Probiotics, prebiotics, and the host microbiome: the science of translation. Ann. N.Y. Acad. Sci. 1306, 1-17. doi: 10.1111/nyas.12303

Piche, T., Barbara, G., Aubert, P., Bruley des Varannes, S., Dainese, R., Nano, J. L., et al. (2009). Impaired intestinal barrier integrity in the colon of patients with irritable bowel syndrome: involvement of soluble mediators. Gut 58, 196-201. doi: 10.1136/gut.2007.140806

Pinto-Sanchez, M. I., Ford, A. C., Avila, C. A., Verdu, E. F., Collins, S. M., Morgan, D., et al. (2015). Anxiety and depression increase in a stepwise manner in parallel with multiple FGIDs and symptom severity and frequency. Am. J. Gastroenterol. 110, 1038-1048. doi: 10.1038/ajg.2015.128

Plöger, S., Stumpff, F., Penner, G. B., Schulzke, J. D., Gäbel, G., Martens, H., et al. (2012). Microbial butyrate and its role for barrier function in the gastrointestinal tract. Ann. N.Y. Acad. Sci. 1258, 52-59. doi: 10.1111/j.17496632.2012.06553.x

Poeze, M., Froon, A. H. M., Greve, J. W. M., and Ramsay, G. (1998). D-lactate as an early marker of intestinal ischaemia after ruptured abdominal aortic aneurysm repair. Br. J. Surg. 85, 1221-1224. doi: 10.1046/j.1365-2168.1998. 00837.x

Pozuelo, M., Panda, S., Santiago, A., Mendez, S., Accarino, A., Santos, J., et al. (2015). Reduction of butyrate- and methane-producing microorganisms in patients with Irritable Bowel Syndrome. Sci. Rep. 5:12693. doi: 10.1038/srep12693

Prenderville, J. A., Kennedy, P. J., Dinan, T. G., and Cryan, J. F. (2015). Adding fuel to the fire: the impact of stress on the ageing brain. Trends Neurosci. 38, 13-25. doi: 10.1016/j.tins.2014.11.001

Qin, H., Zhang, Z., Hang, X., and Jiang, Y. (2009). L. plantarum prevents enteroinvasive Escherichia coli-induced tight junction proteins changes in intestinal epithelial cells. BMC Microbiol. 9:63. doi: 10.1186/1471-2180-9-63
Qin, J., Li, R., Raes, J., Arumugam, M., Burgdorf, K. S., and Manichanh, C. (2010). A human gut microbial gene catalogue established by metagenomic sequencing. Nature 464, 59-65. doi: 10.1038/nature08821

Rajilic-Stojanovic, M., Biagi, E., Heilig, H. G., Kajander, K., Kekkonen, R. A., Tims, S., et al. (2011). Global and deep molecular analysis of microbiota signatures in fecal samples from patients with irritable bowel syndrome. Gastroenterology 141, 1792-1801. doi: 10.1053/j.gastro.2011.07.043

Rajilic-Stojanovic, M., Jonkers, D. M., Salonen, A., Hanevik, K., Raes, J., Jalanka, J., et al. (2015). Intestinal microbiota and diet in IBS: causes, consequences, or epiphenomena? Am. J. Gastroenterol. 110, 278-287. doi: 10.1038/ajg. 2014.427

Rakoff-Nahoum, S., Paglino, J., Eslami-Varzaneh, F., Edberg, S., and Medzhitov, R. (2004). Recognition of commensal microflora by toll-like receptors is required for intestinal homeostasis. Cell 118, 229-241. doi: 10.1016/j.cell.2004.07.002

Rao, A. S., Camilleri, M., Eckert, D. J., Busciglio, I., Burton, D. D., Ryks, M., et al. (2011). Urine sugars for in vivo gut permeability: validation and comparisons in irritable bowel syndrome-diarrhea and controls. Am. J. Physiol. Gastrointest. Liver Physiol. 301, G919-G928. doi: 10.1152/ajpgi.00168.2011

Rao, A. V., Bested, A. C., Beaulne, T. M., Katzman, M. A., Iorio, C., Berardi, J. M., et al. (2009). A randomized, double-blind, placebo-controlled pilot study of a probiotic in emotional symptoms of chronic fatigue syndrome. Gut Pathog. 1:6. doi: 10.1186/1757-4749-1-6

Reigstad, C. S., Salmonson, C. E., Rainey, J. F. III, Szurszewski, J. H., Linden, D. R., Sonnenburg, J. L., et al. (2015). Gut microbes promote colonic serotonin production through an effect of short-chain fatty acids on enterochromaffin cells. FASEB J. 29, 1395-1403. doi: 10.1096/fj.14-259598

Rhee, S. H., Pothoulakis, C., and Mayer, E. A. (2009). Principles and clinical implications of the brain-gut-enteric microbiota axis. Nat. Rev. Gastroenterol. Hepatol. 6, 306-314. doi: 10.1038/nrgastro.2009.35

Roberfroid, M., Gibson, G. R., Hoyles, L., McCartney, A. L., Rastall, R., Rowland, I., et al. (2010). Prebiotic effects: metabolic and health benefits. Br. J. Nutr. 104(Suppl. 2), S1-S63. doi: 10.1017/s0007114510003363

Rodiño-Janeiro, B. K., Alonso-Cotoner, C., Pigrau, M., Lobo, B., Vicario, M., and Santos, J. (2015). Role of corticotropin-releasing factor in gastrointestinal permeability. J. Neurogastroenterol. Motil. 21, 33-50. doi: 10.5056/jnm14084

Rodrigues, D. M., Sousa, A. J., Johnson-Henry, K. C., Sherman, P. M., and Gareau, M. G. (2012). Probiotics are effective for the prevention and treatment of Citrobacter rodentium-induced colitis in mice. J. Infect. Dis. 206, 99-109. doi: 10.1093/infdis/jis177

Rogier, R., Koenders, M. I., and Abdollahi-Roodsaz, S. (2015). Toll-like receptor mediated modulation of $\mathrm{T}$ cell response by commensal intestinal microbiota as a trigger for autoimmune Arthritis. 2015:527696. doi: 10.1155/2015/527696

Rook, G. A., and Lowry, C. A. (2008). The hygiene hypothesis and psychiatric disorders. Trends Immunol. 29, 150-158. doi: 10.1016/j.it.2008.01.002

Rook, G. A., Lowry, C. A., and Raison, C. L. (2013). Microbial 'Old Friends', immunoregulation and stress resilience. Evol. Med. Public Health 2013, 46-64. doi: 10.1093/emph/eot004

Rook, G. A., Martinelli, R., and Brunet, L. R. (2003). Innate immune responses to mycobacteria and the downregulation of atopic responses. Curr. Opin. Allergy Clin. Immunol. 3, 337-342. doi: 10.1097/00130832-200310000-00003

Rook, G. A., Raison, C. L., and Lowry, C. A. (2014). Microbiota, immunoregulatory old friends and psychiatric disorders. Adv. Exp. Med. Biol. 817, 319-356. doi: 10.1007/978-1-4939-0897-4_15

Rosenfeldt, V., Benfeldt, E., Valerius, N. H., Paerregaard, A., and Michaelsen, K. F. (2004). Effect of probiotics on gastrointestinal symptoms and small intestinal permeability in children with atopic dermatitis. J. Pediatr. 145, 612-616. doi: 10.1016/j.jpeds.2004.06.068

Rozee, K. R., Cooper, D., Lam, K., and Costerton, J. W. (1982). Microbial flora of the mouse ileum mucous layer and epithelial surface. Appl. Environ. Microbiol. $43,1451-1463$.

Runtsch, M. C., Round, J. L., and O'Connell, R. M. (2014). MicroRNAs and the regulation of intestinal homeostasis. Front. Genet. 5:347. doi: 10.3389/fgene.2014.00347

Russell, W. R., Hoyles, L., Flint, H. J., and Dumas, M. E. (2013). Colonic bacterial metabolites and human health. Curr. Opin. Microbiol. 16, 246-254. doi: 10.1016/j.mib.2013.07.002

Ruusunen, A., Lehto, S. M., Mursu, J., Tolmunen, T., Tuomainen, T.-P., Kauhanen, J., et al. (2014). Dietary patterns are associated with the prevalence of elevated 
depressive symptoms and the risk of getting a hospital discharge diagnosis of depression in middle-aged or older Finnish men. J. Affect. Disord. 159, 1-6. doi: 10.1016/j.jad.2014.01.020

Sánchez-Villegas, A., Toledo, E., de Irala, J., Ruiz-Canela, M., Pla-Vidal, J., and Martínez-González, M. A. (2012). Fast-food and commercial baked goods consumption and the risk of depression. Public Health Nutr. 15, 424-432. doi: $10.1017 /$ S1368980011001856

Sanders, M. E. (2003). Probiotics: considerations for human health. Nutr. Rev. 61, 91-99. doi: 10.1301/nr.2003.marr.91-99

Sartor, R. B., and Mazmanian, S. K. (2012). Intestinal microbes in inflammatory bowel diseases. Am. J. Gastroenterol. Suppl. 1, 15-21. doi: 10.1038/ajgsup.2012.4

Savignac, H. M., Corona, G., Mills, H., Chen, L., Spencer, J. P., Tzortzis, G., et al. (2013). Prebiotic feeding elevates central brain derived neurotrophic factor, $\mathrm{N}$-methyl-D-aspartate receptor subunits and D-serine. Neurochem. Int. 63, 756-764. doi: 10.1016/j.neuint.2013.10.006

Scaldaferri, F., Gerardi, V., Lopetuso, L. R., Del Zompo, F., Mangiola, F., Boškoski, I., et al. (2013). Gut microbial flora, prebiotics, and probiotics in IBD: their current usage and utility. Biomed. Res. Int. 2013:435268. doi: $10.1155 / 2013 / 435268$

Schmidt, K., Cowen, P. J., Harmer, C. J., Tzortzis, G., Errington, S., and Burnet, P. W. (2015). Prebiotic intake reduces the waking cortisol response and alters emotional bias in healthy volunteers. Psychopharmacology 232, 1793-1801. doi: 10.1007/s00213-014-3810-0

Segawa, S., Fujiya, M., Konishi, H., Ueno, N., Kobayashi, N., Shigyo, T., et al. (2011). Probiotic-derived polyphosphate enhances the epithelial barrier function and maintains intestinal homeostasis through integrin-p38 MAPK pathway. PLoS ONE 6:e23278. doi: 10.1371/journal.pone.0023278

Sengupta, R., Anderson, R. C., Altermann, E., McNabb, W. C., Ganesh, S., Armstrong, K. M., et al. (2015). Lactobacillus fermentum AGR1487 cell surface structures and supernatant increase paracellular permeability through different pathways. Microbiologyopen 4, 541-552. doi: 10.1002/mbo3.260

Seth, A., Yan, F., Polk, D. B., and Rao, R. K. (2008). Probiotics ameliorate the hydrogen peroxide-induced epithelial barrier disruption by a PKC- and MAP kinase-dependent mechanism. Am. J. Physiol. Gastrointest. Liver Physiol. 294, G1060-G1069. doi: 10.1152/ajpgi.00202.2007

Shanahan, F. (2002). Probiotics and inflammatory bowel disease: from fads and fantasy to facts and future. Br. J. Nutr. 88(Suppl. 1), S5-S9. doi: 10.1079/BJN2002624

Shifrin, D. A. Jr., McConnell, R. E., Nambiar, R., Higginbotham, J. N., Coffey, R. J., and Tyska, M. J. (2012). Enterocyte microvillus-derived vesicles detoxify bacterial products and regulate epithelial-microbial interactions. Curr. Biol. 22, 627-631. doi: 10.1016/j.cub.2012.02.022

Silk, D. B., Davis, A., Vulevic, J., Tzortzis, G., and Gibson, G. R. (2009). Clinical trial: the effects of a trans-galactooligosaccharide prebiotic on faecal microbiota and symptoms in irritable bowel syndrome. Aliment. Pharmacol. Ther. 29, 508-518. doi: 10.1111/j.1365-2036.2008.03911.x

Simrén, M. (2014). IBS with intestinal microbial dysbiosis: a new and clinically relevant subgroup? Gut 63, 1685-1686. doi: 10.1136/gutjnl-2013-306434

Singh, P., Agnihotri, A., Pathak, M. K., Shirazi, A., Tiwari, R. P., Sreenivas, V., et al. (2012). Psychiatric, somatic and other functional gastrointestinal disorders in patients with irritable bowel syndrome at a tertiary care center. J. Neurogastroenterol. Motil. 18, 324-331. doi: 10.5056/jnm.2012.18. 3.324

Smith, F., Clark, J. E., Overman, B. L., Tozel, C. C., Huang, J. H., Rivier, J. E. F., et al. (2010). Early weaning stress impairs development of mucosal barrier function in the porcine intestine. Am. J. Physiol. Gastrointest. Liver Physiol. 298, G352-G363. doi: 10.1152/ajpgi.00081.2009

Smythies, L. E., and Smythies, J. R. (2014a). Exosomes in the gut. Front. Immunol. 5:104. doi: 10.3389/fimmu.2014.00104

Smythies, L. E., and Smythies, J. R. (2014b). Microbiota, the immune system, black moods and the brain-melancholia updated. Front. Hum. Neurosci. 8:720. doi: 10.3389/fnhum.2014.00720

Soares, R. L. (2014). Irritable bowel syndrome: a clinical review. World J. Gastroenterol. 20, 12144-12160. doi: 10.3748/wjg.v20.i34.12144

Söderholm, J. D., Yates, D. A., Gareau, M. G., Yang, P. C., MacQueen, G., and Perdue, M. H. (2002). Neonatal maternal separation predisposes adult rats to colonic barrier dysfunction in response to mild stress. Am. J.
Physiol. Gastrointest. Liver Physiol. 283, G1257-G1263. doi: 10.1152/ajpgi.003 14.2002

Sood, R., Gracie, D. J., Law, G. R., and Ford, A. C. (2015). Systematic review with meta-analysis: the accuracy of diagnosing irritable bowel syndrome with symptoms, biomarkers and/or psychological markers. Aliment. Pharmacol. Ther. 42, 491-503. doi: 10.1111/apt.13283

Steele, R. D. (1986). Blood-brain barrier transport of the alpha-keto acid analogs of amino acids. Fed. Proc. 45, 2060-2064.

Steenbergen, L., Sellaro, R., van Hemert, S., Bosch, J. A., and Colzato, L. S. (2015). A randomized controlled trial to test the effect of multispecies probiotics on cognitive reactivity to sad mood. Brain Behav. Immun. 48, 258-264. doi: 10.1016/j.bbi.2015.04.003

Stenman, L. K., Holma, R., and Korpela, R. (2012). High-fat-induced intestinal permeability dysfunction associated with altered fecal bile acids. World J. Gastroenterol. 18, 923-929. doi: 10.3748/wjg.v18.i9.923

Strachan, D. P. (1989). Hay fever, hygiene, and household size. BMJ 299, 1259-1260. doi: 10.1136/bmj.299.6710.1259

Stratiki, Z., Costalos, C., Sevastiadou, S., Kastanidou, O., Skouroliakou, M., Giakoumatou, A., et al. (2007). The effect of a bifidobacter supplemented bovine milk on intestinal permeability of preterm infants. Early Hum. Dev. 83, 575-579. doi: 10.1016/j.earlhumdev.2006.12.002

Sudo, N., Chida, Y., Aiba, Y., Sonoda, J., Oyama, N., Yu, X. N., et al. (2004). Postnatal microbial colonization programs the hypothalamic-pituitaryadrenal system for stress response in mice. J. Physiol. 558, 263-275. doi: 10.1113/jphysiol.2004.063388

Suzuki, T., Yoshida, S., and Hara, H. (2008). Physiological concentrations of shortchain fatty acids immediately suppress colonic epithelial permeability. $\mathrm{Br}$. J. Nutr. 100, 297-305. doi: 10.1017/S0007114508888733

Swanson, P. A. II, Kumar, A., Samarin, S., Vijay-Kumar, M., Kundu, K., Murthy, N., et al. (2011). Enteric commensal bacteria potentiate epithelial restitution via reactive oxygen species-mediated inactivation of focal adhesion kinase phosphatases. Proc. Natl. Acad. Sci. U.S.A. 108, 8803-8808. doi: 10.1073/pnas.1010042108

Swidsinski, A., Loening-Baucke, V., Lochs, H., and Hale, L. P. (2005). Spatial organization of bacterial flora in normal and inflamed intestine: a fluorescence in situ hybridization study in mice. World J. Gastroenterol. 11, 1131-1140. doi: 10.3748/wjg.v11.i8.1131

Taché, Y., and Million, M. (2015). Role of corticotropin-releasing factor signaling in stress-related alterations of colonic motility and hyperalgesia. J. Neurogastroenterol. Motil. 21, 8-24. doi: 10.5056/jnm14162

Teixeira, T. F., Collado, M. C., Ferreira, C. L., Bressan, J., and Peluzio Mdo, C. (2012). Potential mechanisms for the emerging link between obesity and increased intestinal permeability. Nutr. Res. 32, 637-647. doi: 10.1016/j.nutres.2012.07.003

Thabane, M., and Marshall, J. K. (2009). Post-infectious irritable bowel syndrome. World J. Gastroenterol. 15, 3591-3596. doi: 10.3748/wjg.15.3591

Tillisch, K., Labus, J., Kilpatrick, L., Jiang, Z., Stains, J., Ebrat, B., et al. (2013). Consumption of fermented milk product with probiotic modulates brain activity. Gastroenterology 144, 1394-1401, 1401e1-4. doi: 10.1053/j.gastro.2013.02.043

Tlaskalová-Hogenova, H., Stěpanková, R., Kozáková, H., Hudcovic, T., Vannucci, L., Tučková, L., et al. (2011). The role of gut microbiota (commensal bacteria) and the mucosal barrier in the pathogenesis of inflammatory and autoimmune diseases and cancer: contribution of germ-free and gnotobiotic animal models of human diseases. Cell. Mol. Immunol. 8, 110-120. doi: 10.1038/cmi.2010.67

Ukena, S. N., Singh, A., Dringenberg, U., Engelhardt, R., Seidler, U., Hansen, W., et al. (2007). Probiotic Escherichia coli Nissle 1917 inhibits leaky gut by enhancing mucosal integrity. PLOS ONE 2:e1308. doi: 10.1371/journal.pone.0001308

Ulluwishewa, D., Anderson, R. C., McNabb, W. C., Moughan, P. J., Wells, J. M., and Roy, N. C. (2011). Regulation of tight junction permeability by intestinal bacteria and dietary components. J. Nutr. 141, 769-776. doi: 10.3945/jn.110.135657

Vaarala, O., Atkinson, M. A., and Neu, J. (2008). The "perfect storm" for type 1 diabetes: the complex interplay between intestinal microbiota, gut permeability, and mucosal immunity. Diabetes 57, 2555-2562. doi: 10.2337/ db08-0331 
van Ampting, M. T., Schonewille, A. J., Vink, C., Brummer, R. J., van der Meer, R., and Bovee-Oudenhoven, I. M. (2010). Damage to the intestinal epithelial barrier by antibiotic pretreatment of salmonella-infected rats is lessened by dietary calcium or tannic acid. J. Nutr. 140, 2167-2172. doi: 10.3945/jn.110.124453

van Passel, M. W., Kant, R., Zoetendal, E. G., Plugge, C. M., Derrien, M., Malfatti, S. A., et al. (2011). The genome of Akkermansia muciniphila, a dedicated intestinal mucin degrader, and its use in exploring intestinal metagenomes. PLoS ONE 6:e16876. doi: 10.1371/journal.pone.0016876

Vanuytsel, T., van Wanrooy, S., Vanheel, H., Vanormelingen, C., Verschueren, S., Houben, E., et al. (2014). Psychological stress and corticotropin-releasing hormone increase intestinal permeability in humans by a mast cell-dependent mechanism. Gut 63, 1293-1299. doi: 10.1136/gutjnl-2013-305690

Verhasselt, V. (2010). Neonatal tolerance under breastfeeding influence: the presence of allergen and transforming growth factor-beta in breast milk protects the progeny from allergic asthma. J. Pediatr. 156, S16-S20. doi: 10.1016/j.jpeds.2009.11.015

Vicario, M., González-Castro, A. M., Martinez, C., Lobo, B., Pigrau, M., Guilarte, M., et al. (2015). Increased humoral immunity in the jejunum of diarrhoeapredominant irritable bowel syndrome associated with clinical manifestations. Gut 64, 1379-1388. doi: 10.1136/gutjnl-2013-306236

Vijay, N., and Morris, M. E. (2014). Role of monocarboxylate transporters in drug delivery to the brain. Curr. Pharm. Des. 20, 1487-1498. doi: $10.2174 / 13816128113199990462$

Villani, A. C., Lemire, M., Thabane, M., Belisle, A., Geneau, G., Garg, A. X., et al. (2010). Genetic risk factors for post-infectious irritable bowel syndrome following a waterborne outbreak of gastroenteritis. Gastroenterology 138, 1502-1513. doi: 10.1053/j.gastro.2009.12.049

Voreades, N., Kozil, A., and Weir, T. L. (2014). Diet and the development of the human intestinal microbiome. Front. Microbiol. 5:494. doi: $10.3389 /$ fmicb. 2014.00494

W. H. O. (2001). Joint Food and Agriculture Organization of the United Nations"Health and Nutritional Properties of Probiotics in Food Including Powder Milk with Live Lactic Acid Bacteria." Rome; Geneva: FAO-WHO.

Walker, J. R., Ediger, J. P., Graff, L. A., Greenfeld, J. M., Clara, I., Lix, L., et al. (2008). The Manitoba IBD cohort study: a population-based study of the prevalence of lifetime and 12-month anxiety and mood disorders. Am. J. Gastroenterol. 103, 1989-1997. doi: 10.1111/j.1572-0241.2008.01980.x

Wang, H. B., Wang, P. Y., Wang, X., Wan, Y. L., and Liu, Y. C. (2012a). Butyrate enhances intestinal epithelial barrier function via up-regulation of tight junction protein Claudin-1 transcription. Dig. Dis. Sci. 57, 3126-3135. doi: $10.1007 / \mathrm{s} 10620-012-2259-4$

Wang, S. X., and Wu, W. C. (2005). Effects of psychological stress on small intestinal motility and bacteria and mucosa in mice. World J. Gastroenterol. 11, 2016-2021. doi: 10.3748/wjg.v11.i13.2016

Wang, Y., Liu, Y., Sidhu, A., Ma, Z., McClain, C., and Feng, W. (2012b). Lactobacillus rhamnosus GG culture supernatant ameliorates acute alcoholinduced intestinal permeability and liver injury. Am. J. Physiol. Gastrointest. Liver Physiol. 303, G32-G41. doi: 10.1152/ajpgi.00024.2012

Weissman. (1992). The changing rate of major depression. Cross-national comparisons. cross-national collaborative group. JAMA 268, 3098-3105. doi: 10.1001/jama.1992.03490210080039

Whelan, K., and Quigley, E. M. (2013). Probiotics in the management of irritable bowel syndrome and inflammatory bowel disease. Curr. Opin. Gastroenterol. 29, 184-189. doi: 10.1097/MOG.0b013e32835d7bba,

Williamson, L. L., McKenney, E. A., Holzknecht, Z. E., Belliveau, C., Rawls, J. F., Poulton, S., et al. (2015). Got worms? Perinatal exposure to helminths prevents persistent immune sensitization and cognitive dysfunction induced by early-life infection. Brain Behav. Immun. doi: 10.1016/j.bbi.2015.07.006. [Epub ahead of print].

Willing, B. P., Russell, S. L., and Finlay, B. B. (2011). Shifting the balance: antibiotic effects on host-microbiota mutualism. Nat. Rev. Microbiol. 9, 233-243. doi: 10.1038/nrmicro2536

Wu, L. L., Chiu, H. D., Peng, W. H., Lin, B. R., Lu, K. S., Lu, Y. Z., et al. (2011). Epithelial inducible nitric oxide synthase causes bacterial translocation by impairment of enterocytic tight junctions via intracellular signals of Rho-associated kinase and protein kinase C zeta. Crit. Care Med. 39, 2087-2098. doi: 10.1097/CCM.0b013e31821cb40e

Yang, H., Zhao, X., Tang, S., Huang, H., Zhao, X., Ning, Z., et al. (2014). Probiotics reduce psychological stress in patients before laryngeal cancer surgery. Asia Pac. J. Clin. Oncol. doi: 10.1111/ajco.12120. [Epub ahead of print].

Yano, J. M., Yu, K., Donaldson, G. P., Shastri, G. G., Ann, P., Ma, L., et al. (2015). Indigenous bacteria from the gut microbiota regulate host serotonin biosynthesis. Cell 161, 264-276. doi: 10.1016/j.cell.2015.02.047

Yoon, J. S., Sohn, W., Lee, O. Y., Lee, S. P., Lee, K. N., Jun, D. W., et al. (2014). Effect of multi-species probiotics on irritable bowel syndrome: a randomized, double-blind, placebo-controlled trial. J. Gastroenterol. Hepatol. 29, 52-59. doi: 10.1111/jgh.12322

Yu, L. C., Wang, J. T., Wei, S. C., and Ni, Y. H. (2012). Host-microbial interactions and regulation of intestinal epithelial barrier function: from physiology to pathology. World J. Gastrointest. Pathophysiol. 3, 27-43. doi: 10.4291/wjgp.v3.i1.27

Zakostelska, Z., Kverka, M., Klimesova, K., Rossmann, P., Mrazek, J., Kopecny, J., et al. (2011). Lysate of probiotic Lactobacillus casei DN-114 001 ameliorates colitis by strengthening the gut barrier function and changing the gut microenvironment. PLOS ONE 6:e27961. doi: 10.1371/journal.pone.00 27961

Zareie, M., Johnson-Henry, K., Jury, J., Yang, P. C., Ngan, B. Y., McKay, D. M., et al. (2006). Probiotics prevent bacterial translocation and improve intestinal barrier function in rats following chronic psychological stress. Gut 55, 1553-1560. doi: 10.1136/gut.2005.080739

Zeissig, S., Bürgel, N., Günzel, D., Richter, J., Mankertz, J., Wahnschaffe, U., et al. (2007). Changes in expression and distribution of claudin 2, 5 and 8 lead to discontinuous tight junctions and barrier dysfunction in active Crohn's disease. Gut 56, 61-72. doi: 10.1136/gut.2006.094375

Zeng, J., Li, Y. Q., Zuo, X. L., Zhen, Y. B., Yang, J., and Liu, C. H. (2008). Clinical trial: effect of active lactic acid bacteria on mucosal barrier function in patients with diarrhoea-predominant irritable bowel syndrome. Aliment. Pharmacol. Ther. 28, 994-1002. doi: 10.1111/j.1365-2036.2008.03818.x

Zhong, Y., Cai, D., Cai, W., Geng, S., Chen, L., and Han, T. (2009). Protective effect of galactooligosaccharide-supplemented enteral nutrition on intestinal barrier function in rats with severe acute pancreatitis. Clin. Nutr. 28, 575-580. doi: 10.1016/j.clnu.2009.04.026

Zijlmans, M. A. C., Korpela, K., Riksen-Walraven, J. M., de Vos, W. M., and de Weerth, C. (2015). Maternal prenatal stress is associated with the infant intestinal microbiota. Psychoneuroendocrinology 53, 233-245. doi: 10.1016/j.psyneuen.2015.01.006

Zonis, S., Pechnick, R. N., Ljubimov, V. A., Mahgerefteh, M., Wawrowsky, K., Michelsen, K. S., et al. (2015). Chronic intestinal inflammation alters hippocampal neurogenesis. J. Neuroinflammation 12, 65. doi: 10.1186/s12974015-0281-0

Zyrek, A. A., Cichon, C., Helms, S., Enders, C., Sonnenborn, U., and Schmidt, M. A. (2007). Molecular mechanisms underlying the probiotic effects of Escherichia coli Nissle 1917 involve ZO-2 and PKCzeta redistribution resulting in tight junction and epithelial barrier repair. Cell. Microbiol. 9, 804-816. doi: 10.1111/j.1462-5822.2006.00836.x

Conflict of Interest Statement: The Microbiome Institute has conducted studies in collaboration with several companies including GSK, Pfizer, Wyeth and Mead Johnson. The authors declare that the research was conducted in the absence of any commercial or financial relationships that could be construed as a potential conflict of interest.

Copyright (c) 2015 Kelly, Kennedy, Cryan, Dinan, Clarke and Hyland. This is an open-access article distributed under the terms of the Creative Commons Attribution License (CC BY). The use, distribution or reproduction in other forums is permitted, provided the original author(s) or licensor are credited and that the original publication in this journal is cited, in accordance with accepted academic practice. No use, distribution or reproduction is permitted which does not comply with these terms. 